\title{
The start-up of the Dolomia Principale/Hauptdolomit carbonate platform (Upper Triassic) in the eastern Southern Alps
}

\author{
MARCELLO CAGGIATI* ID, PIERO GIANOLLA*, ANNA BREDA†, BOGOMIR \\ CELARC + and NEREO PRETO $\dagger$ \\ *Physics and Earth Sciences Department, University of Ferrara, Via Saragat, 1, Ferrara 44100, Italy, \\ (E-mail: marcello.caggiati@unife.it) \\ $\dagger$ Geosciences Department, University of Padua, Via Gradenigo, 6, Padua 35131, Italy \\ $\$$ Geological Survey of Slovenia, Dimičeva ulica 14, Ljubljana SI-1000, Slovenia
}

Associate Editor - Gregor Eberli

\begin{abstract}
Wide carbonate platform environments developed on the western passive margin of the Tethys during the Late Triassic, after a major climate change (Carnian Pluvial Episode) that produced a crisis of high-relief microbial carbonate platforms. The peritidal succession of this epicontinental platform (Dolomia Principale/Hauptdolomit, Dachstein Limestone) is widespread in the Mediterranean region. However, the start-up stage is not fully understood. The original platform to basin depositional geometries of the system have been studied in the north-eastern Southern Alps, close to the Italian/ Slovenian boundary where they are exceptionally preserved. Sedimentological features have been investigated in detail by measuring several stratigraphic sections cropping out along an ideal depositional profile. The analysis of the facies architecture allowed reconstruction of the palaeoenvironments of the Dolomia Principale platform during its start-up and early growth stages in the late Carnian. The carbonate platform was characterized by an outer platform area, connected northward to steep slopes facing a relatively deep basin. Southward, the outer platform was connected to inner sheltered environments by a narrow, often emerged shelf crest. Behind this zone, carbonate sedimentation occurred in shallow lagoons and tidal flats, passing inward to a siliciclastic mudflat. The Dolomia Principale platform was initially aggrading and able to keep pace with a concomitant sea-level rise, and then prograding during the late Carnian. This stratigraphic interval was correlated with the Tuvalian succession of the Dolomites, allowing depiction of the depositional system on a wide scale of hundreds of kilometres. This large-scale depositional system presents features in common with some Palaeozoic and Mesozoic carbonate build-ups (for example, the Permian Capitan Reef complex, Anisian Latemar platform), both in terms of architecture and prevailing carbonate producers. A microbial-dominated carbonate factory is found in the outer platform and upper slope. The recovery of high-relief microbial carbonate platforms marks the end of the Carnian Pluvial Episode in the Tuvalian of Tethys.
\end{abstract}

Keywords Carbonate factories, carbonate platforms, facies model, microbialites, Triassic, Western Tethys. 


\section{INTRODUCTION}

During the Triassic, the Tethys saw the progressive development of carbonate platforms of increasingly larger scale and relief, from isolated occurrences of carbonate build-ups during the Induan and Olenekian (Lehrmann et al., 1998, 2005), to kilometre-scale isolated and epicontinental high-relief platforms in the Anisian, Ladinian and lower Carnian (Stefani et al., 2010). The majority of these carbonate platforms are mostly made of microbialites rather than metazoan skeletons (Blendinger, 1994; Russo et al., 1997; Kiessling, 2009; Martindale et al., 2015). The spread and increase in scale of Triassic carbonate platforms is particularly well-documented in the Dolomites of Northern Italy (Gaetani et al., 1981; Bosellini, 1984; Stefani et al., 2010). In this region, where the continuity and resolution of the sedimentary record is exceptional, it can be shown that the growth of Triassic carbonate platforms was a process in steps, with frequent interruptions (De Zanche et al., 1993; Gianolla et al., 1998). One of these halts in carbonate production is related to a major climate change and carbon isotope excursion, the Carnian Pluvial Event (CPE; Simms \& Ruffell, 1989; Dal Corso et al., 2015). During the CPE, microbial carbonates were replaced by skeletal grains and ooids, and carbonate platforms could not achieve a substantial depositional relief (Stefani et al., 2010; Gattolin et al., 2015). At the end of this event, a single, continental-scale carbonate platform developed nearly everywhere in Western Tethys during the Late Carnian and Norian/Rhaetian.

The Dolomia Principale/Hauptdolomit is one of the most known lithostratigraphic units of the Alpine Upper Triassic (Guembel, 1857; Lepsius, 1876; Bosellini, 1967; Fruth \& Scherreiks, 1984; Bosellini \& Hardie, 1985; Carulli et al., 2000; Berra et al., 2010, and references therein), mainly representing a monotonous thick succession of inner platform facies related to this wide epicontinental platform bordering the Triassic Tethys.

It is recorded from the Southern Alps to the Austroalpine nappes (for example, Northern Calcareous Alps, Drau Range; Tollmann, 1977, 1980; Mandl, 2000), as well as in the Transdanubian Range (Fődolomit; Kovács et al., 2011; Haas, 2012; Haas et al., 2015) and External Dinarides-Albanides (Glavni/Main Dolomite; Vlahović et al., 2005; Dozet \& Buser, 2009).

Despite its vast extent, the margin to slope facies of the Dolomia Principale/Hauptdolomit platform are well-known only from Norian and Rhaetian times, and mostly for local settings facing poorly oxygenated intraplatform basins and/ or open pelagic areas (Iannace \& Zamparelli, 2002; Cozzi \& Hardie, 2003; Jadoul et al., 2004). Conversely, the early-stage marginal systems are known only from Julian Alps, and remain poorly studied, with a few significant exceptions (Gianolla et al., 2003; Celarc \& Kolar-Jurkovšek, 2008). This means that the facies, depositional geometries and carbonate producers of the larger and most long-lived Tethyan carbonate platform system of the Triassic are nearly unknown in its early stage.

The aim of this work was to contribute towards filling this gap, by proposing a comprehensive facies model of the late Carnian portion of the Dolomia Principale/Hauptdolomit carbonate platform system in a palaeogeographic setting facing a branch of the Tethys ocean (the Tarvisio Basin: Gianolla et al., 2003; Gale et al., 2015). Furthermore, this study aimed to provide new data on the type of this late Carnian carbonate factory at its seaward margin. The start-up stage of the Dolomia Principale/Hauptdolomit carbonate platform has been investigated in the eastern Southern Alps (Fig. 1) by analysing several sections with multi-disciplinary methods including facies analysis, biostratigraphy and sequence stratigraphy.

\section{GEOLOGICAL SETTING}

The platform system has been analysed in the western Julian Alps and eastern Carnia (northeast Italy and north-west Slovenia; Fig. 1) that are part of the eastern Southern Alps fold and thrust belt (Castellarin et al., 2006). The investigated area represents one of the best places to link the almost barren Upper Carnian inner platform system with its eteropic, biostratigraphically well-constrained, basinal counterpart (Fig. 2), and the margin system is indeed exposed for more than $5 \mathrm{~km}$ in a ESE-WNW direction. Despite the fact that the whole region is affected by polyphase tectonics resulting in a complex structural framework, the study area falls into a single tectonic unit in which displacements are relatively limited. Major faults bounding the unit are represented by the (currently) dextral strike-slip Fella-Sava Line to the north, and by the Val Resia-Val Coritenza fault system to the south and to the east as the hangingwall (Ponton, 2010; Gale et al., 2015). 


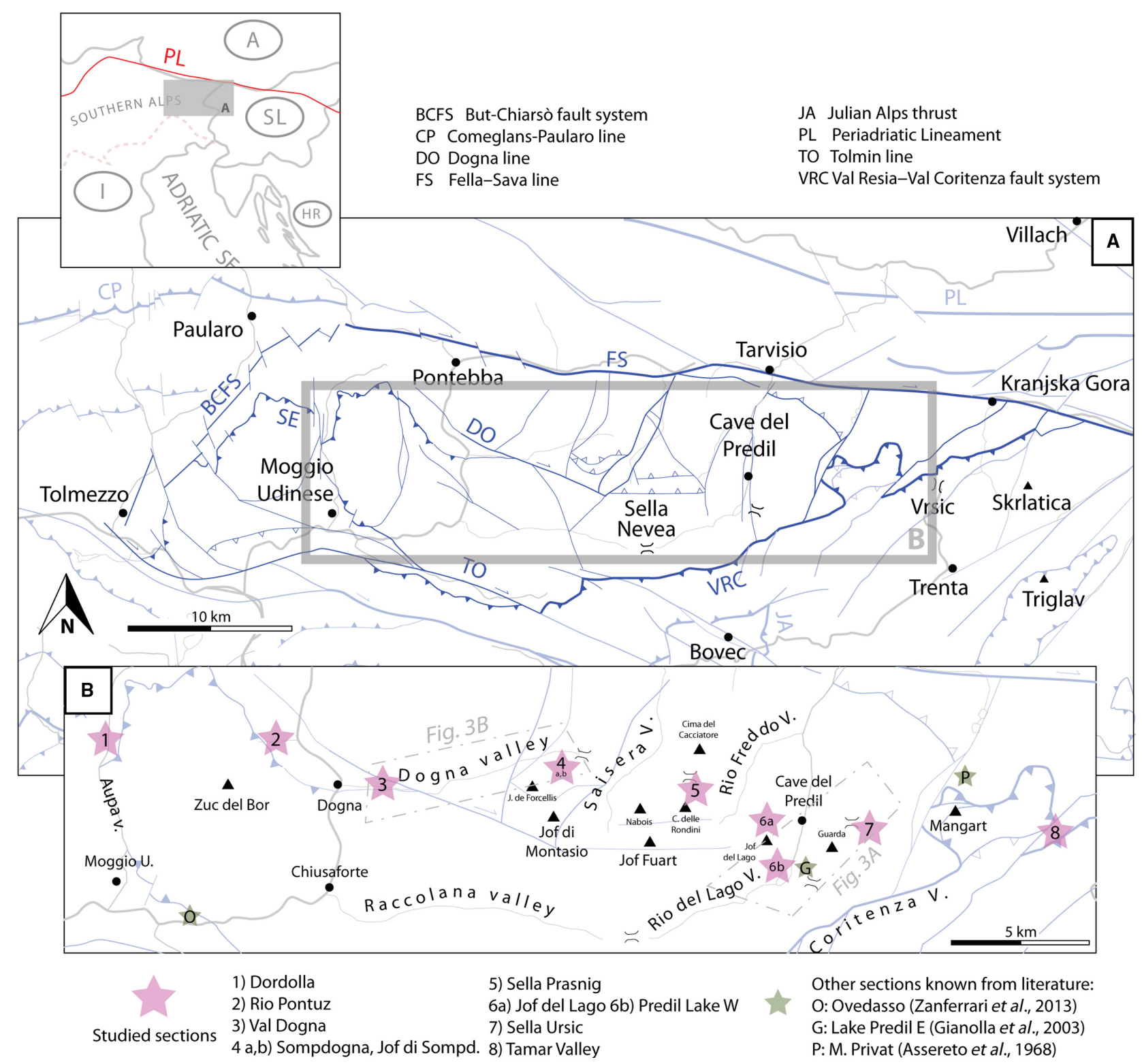

Fig. 1. Location of investigated area and simplified structural framework of the eastern Southern Alps. (A) The area is part of a single thrust-unit and tectonic displacements inside it are quite limited. Analysed sections are displayed in the enlargement below. (B) After Assereto et al. (1968), Bianchin et al. (1980), Venturini (2002), Ponton (2010), Zanferrari et al. (2013) and Gale et al. (2015).

\section{MATERIALS AND METHODS}

The start-up stage of the Dolomia Principale/ Hauptdolomit carbonate platform was investigated in detail by measuring ten composite stratigraphic sections placed along the ideal platform-dip profile (Fig. 1; Table S1) and by analysing the depositional record with a multidisciplinary approach. In order to support the physical correlation of stratigraphic sections; which are scattered over a $c a 150 \mathrm{~km}^{2}$ area, the Mesozoic cover was mapped where geological maps from literature were missing or incorrect (for example, Fig. 3).

A preliminary macrofacies analysis was carried out on the field for each geological section, using a centimetre to decimetre-scale resolution. Microfacies analysis has been performed in the most interesting intervals, with 155 thin sections analysed by transmitted light microscopy. In strongly dolomitized samples, thin section images have been post-processed by filtering and/or modifying band colour curves in order to improve the visibility of sedimentological textures. 


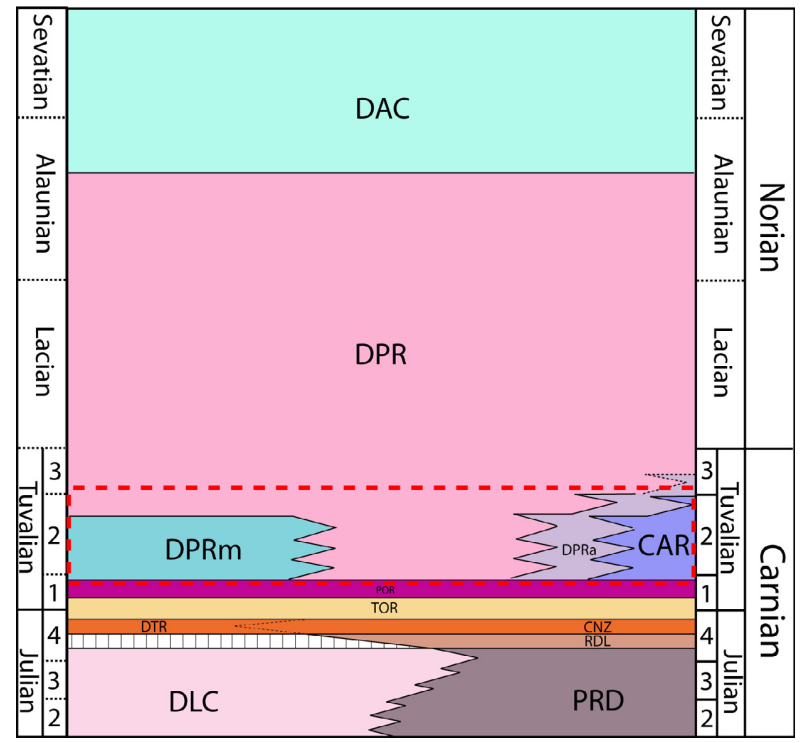

Fig. 2. Chronostratigraphic scheme of the investigated succession in the western Julian Alps. The studied interval, Upper Tuvalian in age, is outlined by the red dashed line. Numbers in Carnian substages indicate progressive ammonoid zones as in Balini et al. (2010). Black dotted lines indicate poor time constraints. DAC, Dachstein Limestone; DPR, Dolomia Principale (inner platform); DPRa, Dolomia Principale (massive to clinobedded); DPRm, Dolomia Principale, Monticello Member; CAR, Carnitza Formation; POR, Portella dolomite; TOR, Tor Formation; CNZ, Conzen Limestone; RTR, Rio di Terrarossa dolomite; RDL, Rio del Lago Formation; PRD, Predil Limestone; DLC, Ladinian-Carnian dolomite.

\section{STRATIGRAPHY}

The investigated region was characterized in the early Carnian by high-relief carbonate platforms (Schlern Dolomite auct.) facing both relatively deep basins (San Cassiano Formation; Jadoul \& Nicora, 1979) and disoxic intraplatform troughs (Predil Limestone; Assereto et al., 1968), with a complex palaeogeography. Basin infilling by siliciclastics and transition to low-angle carbonate systems (i.e. ramps) are recorded by the Rio del Lago Formation and subsequently by the Conzen Formation (De Zanche et al., 2000, and references therein). Due to a variable availability of accommodation space, the aforementioned Lower Carnian stratigraphic units may locally be missing or may show complex stratigraphic relationships (Fig. 2).

A more uniform stratigraphy is observed from the uppermost Lower Carnian, characterized everywhere by the Tor Formation (representing a mixed carbonate-siliciclastic ramp environment; De Zanche et al., 2000; Preto et al., 2005). In the upper part of this unit, nodular to platy limestones, marly limestones, marls and black pelite alternations are arranged in a shallowing-upward trend (Lieberman, 1978; De Zanche et al., 2000). Uppermost layers contain shallow-water fauna and plant debris, the latter pointing to a significant continental supply of organic material. An upper Julian to lower Tuvalian age has been postulated for this unit, based on ammonoid findings (De Zanche et al., 2000), palynomorph associations (Roghi, 2004) and bivalves (Ruvinetti, 2004).

The transition to the overlying Portella dolomite (De Zanche et al., 2000) is characterized by common dolomitization of topmost beds (Fig. 4). The Portella dolomite is characterized by an almost constant thickness ( $c a 15 \mathrm{~m}$ ). It consists mainly of crystalline dolostones organized in metre thick beds, with dolomitization obliterating fossils and sedimentary structures. Only in the type locality (Sella Ursic) do horizontal laminations occur, in association with peritidal grainstones-rudstones (intraclasts, coated grains and bivalve ghosts) and stromatolite bindstones (De Zanche et al., 2000). Pelite is absent and bedding planes often become wavy in the upper part. The Portella dolomite can be correlated with analogous lithostratigraphic units over large distances (De Zanche et al., 2000; Breda et al., 2009; Zanferrari et al., 2013), yielding fossil assemblages of lower Tuvalian age (Dilleri ammonoid zone). Its top is characterized by the sharp transition to lithostratigraphic units (Fig. 2) related to the emplacement of the Dolomia Principale depositional system. This study focuses on the description of this depositional system, at the time of its inception.

\section{Main lithostratigraphic units of the Dolomia Principale depositional system}

North of a WNW-ESE-oriented belt striking from M. Guarda (south-east of Cave del Predil) to the upper Dogna Valley, a basinal unit named the Carnitza Formation is present, consisting of pelagic nodular limestones with pelite intercalations and containing middle to upper Tuvalian ammonoids (Subbullatus and Spinosus zones; Gianolla et al., 2003) and conodonts (Lieberman, 1978; Gale et al., 2015). The Carnitza Formation is characterized by a thickening/coarsening upward trend in the upper part, where it interfingers with thick clinoforms and massive dolostones representing the slope and marginal 
A
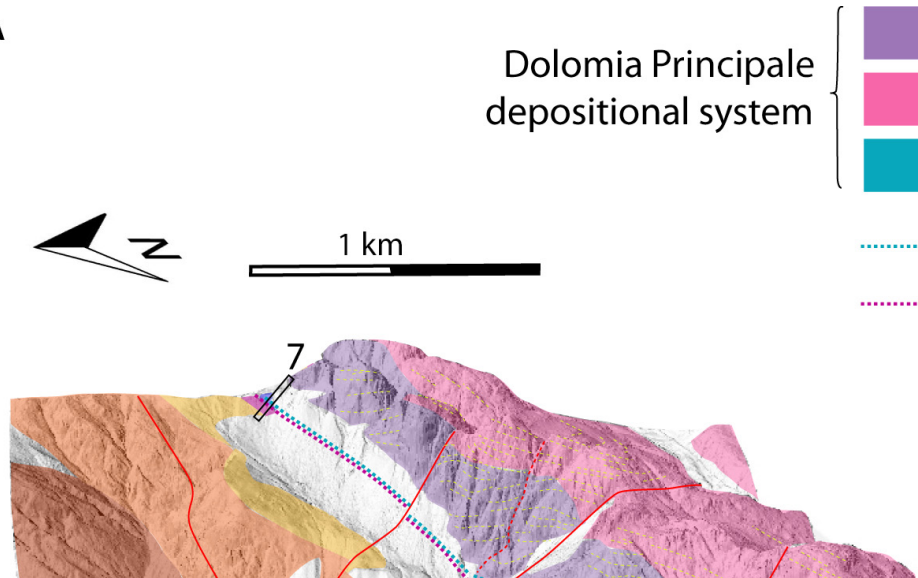

Massive to clinobeds

Inner platform - carb. cycles

Inner platform - carb./silic. cycles

Platform-basin physical correlation

Basal reference horizon

(Portella dolomite top)

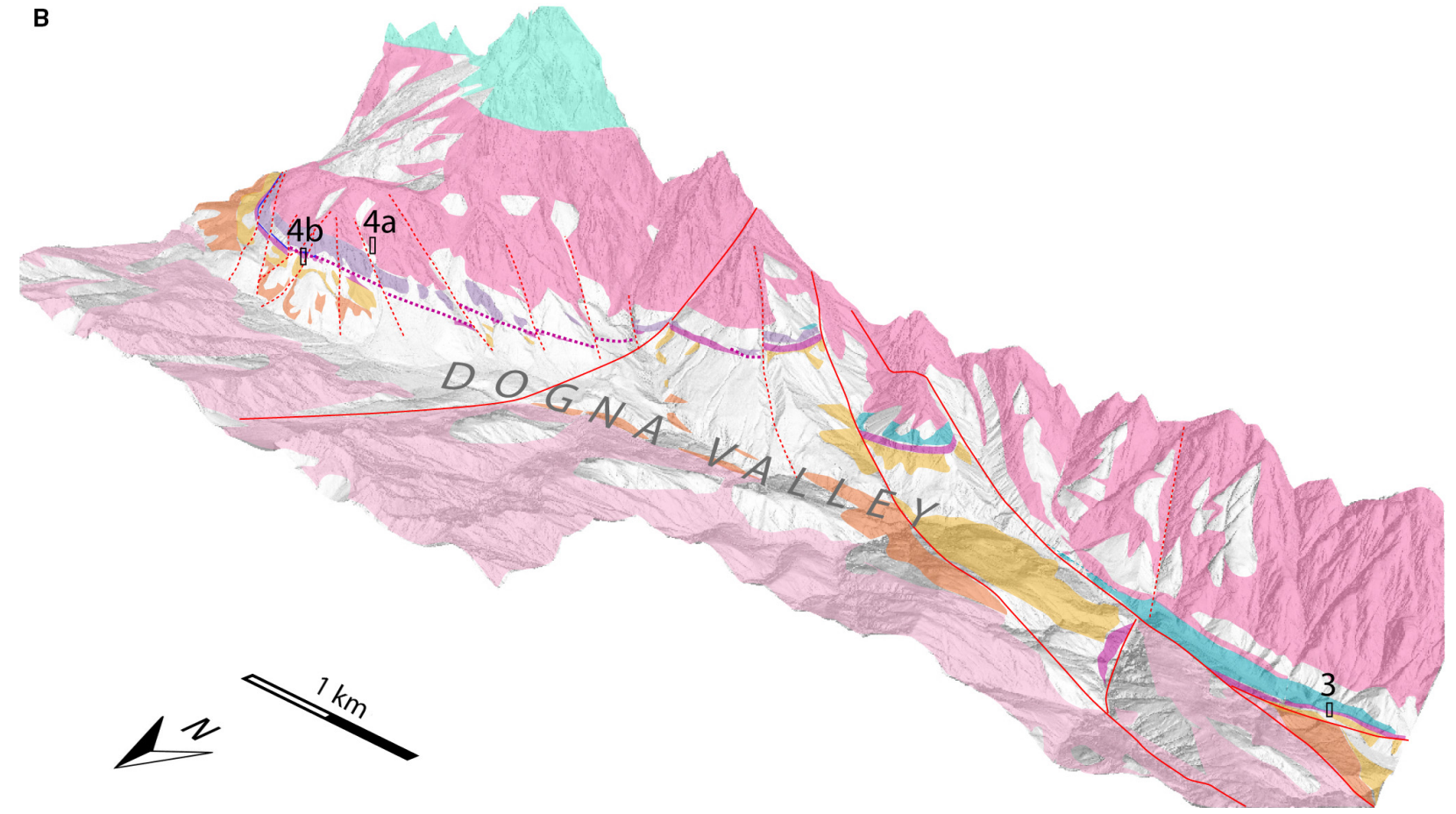

Fig. 3. Three-dimensional geological map of the Cave del Predil valley (A) and upper Dogna valley (B); see Fig. 1 for position. Despite tectonic displacements, the original stratigraphic relationships are well-recognizable and physical correlations are possible. Colours as in Fig. 2. Numbers and rectangles refer to investigated sections (Figs 1 and 4). 

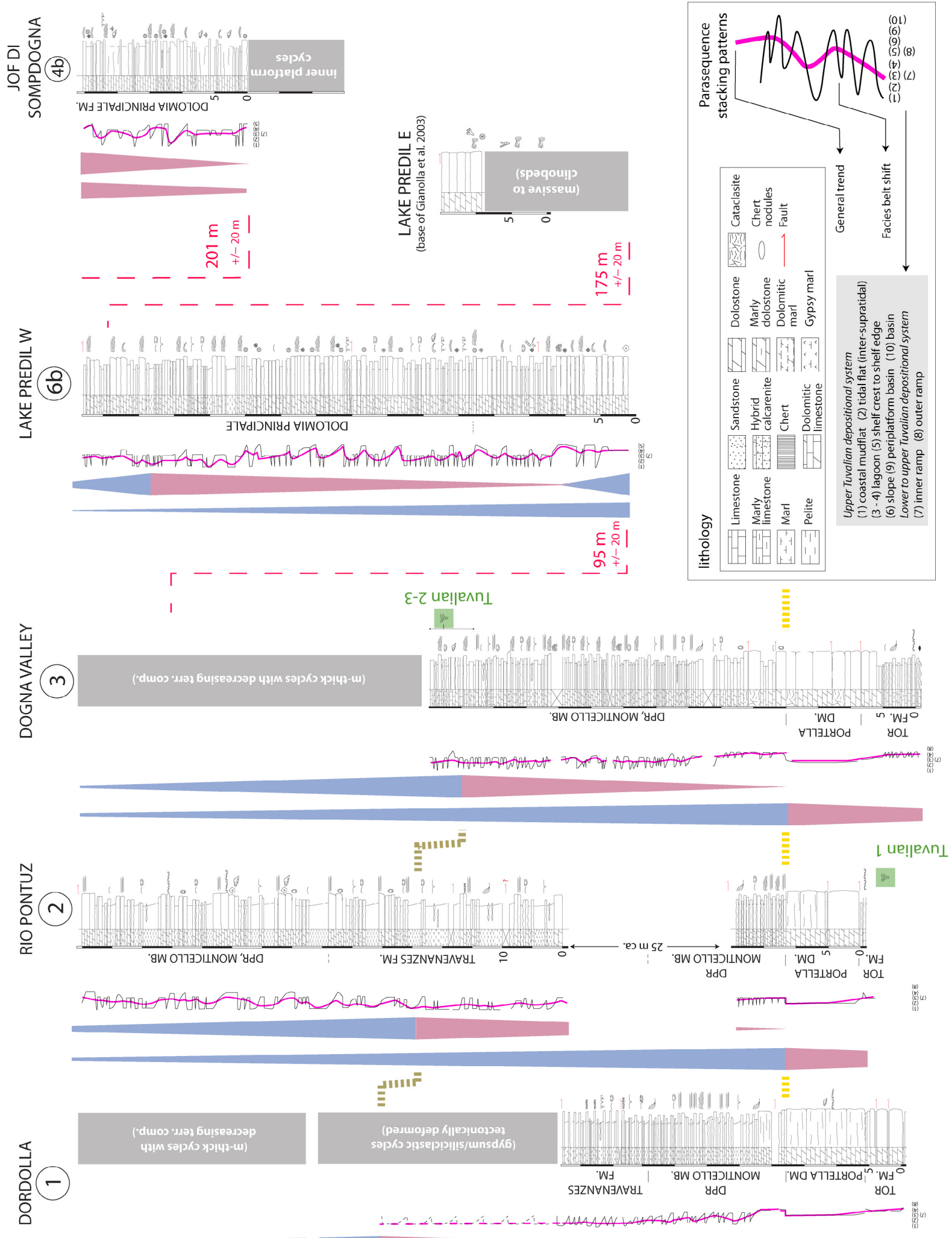
Fig. 4. Simplified stratigraphic logs of analysed sections (see Fig. 1 for location) and relative environmental interpretation. The top of the Portella dolomite has been chosen as the reference horizon to align different stratigraphic sections. For each section, the inferred depositional environments (black line on the left) outline progradational or retrogradational parasequences. Pink and light blue triangles outline higher order transgressive/ regressive trends. Green squares indicate available biostratigraphic data; the corresponding ammonoid biozone range is shown laterally (Tuvalian 1: Tropites dilleri zone; Tuvalian 2: Tropites subbullatus zone; Tuvalian 3: Anatropites spinosus zone). The Sella Ursic composite section has been revised after Gianolla et al. (2003). The Jof del Lago section partially fits with that of Assereto et al. (1968) and Tamar Valley section has been presented in Gale et al. (2015).

facies of the adjacent Dolomia Principale carbonate platform. Exceptions are the M. Privat and Tamar Valley sections, located to the east (Fig. 1), where the topmost part of the Carnitza Formation exhibits strong dolomitization and contains chert nodules, the latter suggestive of persistent basinal conditions (Bača Formation, late Tuvalian; Gale et al., 2015). The total thickness of the Carnitza Formation ranges from 20 to $80 \mathrm{~m}$ (Fig. 4), depending on the distance from the carbonate platform.

Clinostratified and massive dolostones, representing the facies margin of the Dolomia Principale carbonate platform (Assereto et al., 1968; De Zanche et al., 2000; Gianolla et al., 2003), crop out along a WNW-ESE-oriented belt. South of this belt, a thick succession of well-bedded dolostones are found (Dolomia Principale Formation) (Fig. 3A). The succession can be split into a lower part (up to $200 \mathrm{~m}$ thick), characterized by dark clay intercalations, and an upper part (>500 $\mathrm{m}$ in thickness) where the siliciclastic component is absent or reduced to millimetre thick partings. West of the Jôf de Forcellis peak (right side of upper Dogna Valley), the lower part is heteropic to a mixed carbonate-siliciclastic succession (Fig. 3B) with a more consistent terrigenous component and total thicknesses increasing south-westward (Monticello Member, Dolomia Principale). Towards the eastern Carnia region, more to the west, the Monticello Member shows lateral and vertical heteropic transition to a thick, fine-grained, mainly siliciclastic succession (Travenanzes Formation), in which carbonates are reduced to thin beds of aphanotopic dolostones, vuggy dolostones or occasional gypsum-anhydrite lens (Carulli et al., 1987; Zanferrari et al., 2013). The overall thickness of the Monticello and Travenanzes formations is $>250 \mathrm{~m}$. An upper Tuvalian age has been determined for the Monticello Member based on palynomorph biostratigraphy (Granuloperculatipollis rudis assemblage; Roghi \& Dalla Vecchia, 1997; Preto et al., 2005; Avanzini et al., 2007). A gradual decrease in pelite interbeds marks the transition to the overlying peritidal cycles of the Dolomia Principale, which is at least $500 \mathrm{~m}$ thick here. Well-bedded metre thick, peritidal asymmetrical cycles consist of subtidal, megalodon-rich dolostones, intrabioclastic doloarenites and supratidal stromatolites, sometimes capped by tepee structures (Bosellini \& Hardie, 1985).

\section{UPPER CARNIAN PLATFORM TO BASIN DEPOSITIONAL SYSTEM}

The Upper Carnian succession has been investigated in detail on an approximately east-west profile (Fig. 1). Macrofacies and microfacies analysis allowed reconstruction of the upper Tuvalian depositional system, representing the onset of the Dolomia Principale carbonate platform. The well-preserved geometries and relationships of sedimentary bodies (Figs 3 and 5) aided in modelling the original platform. Facies descriptions are in Table 1, facies associations and depositional environments are presented in Table 2 and summarized below.

\section{Basin}

Facies Association 1 (FA1)

Wackestones-packstones rich in pelagic bioclasts (especially pelecypods, locally calcispheres and radiolarians), organized in centimetre to decimetre thick beds (facies A1 and A2; Table 1) alternating with millimetre thick dark pelites (facies A3; Table 1; Fig. 6A to C). Indistinct plane-parallel lamination to wavy and nodular beds is observed. The fine-grained component suggests a low hydrodynamic depositional setting. The preserved stratigraphic relationships with the adjacent carbonate platform (Fig. 3) led to the interpretation that this facies association was deposited within a $c a 300 \mathrm{~m}$ deep periplatform basin. Deep-water sedimentation is also confirmed by the presence of chert nodules and lenses, at places occurring in wackestones 

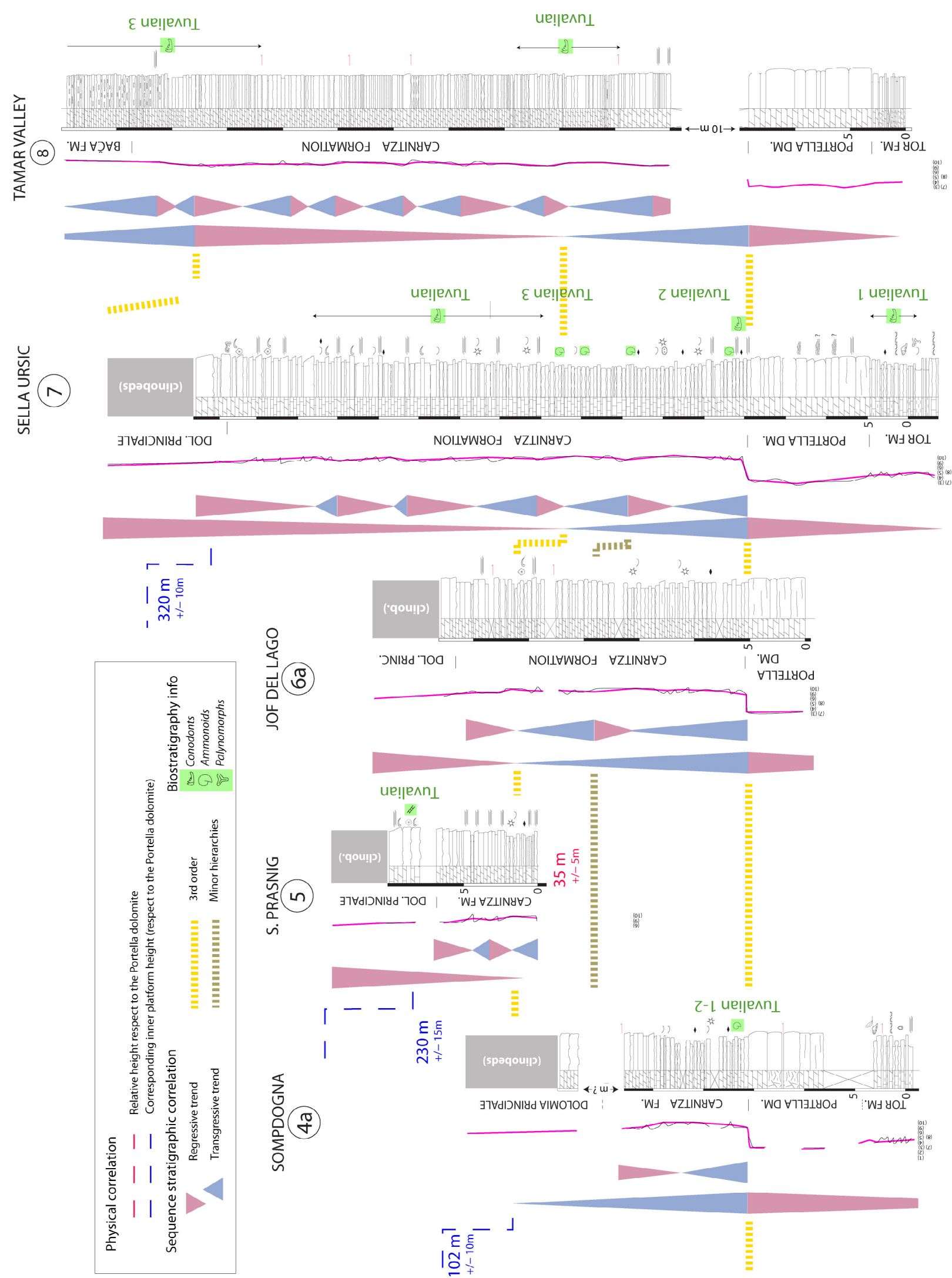

Fig. 4. Continued. 

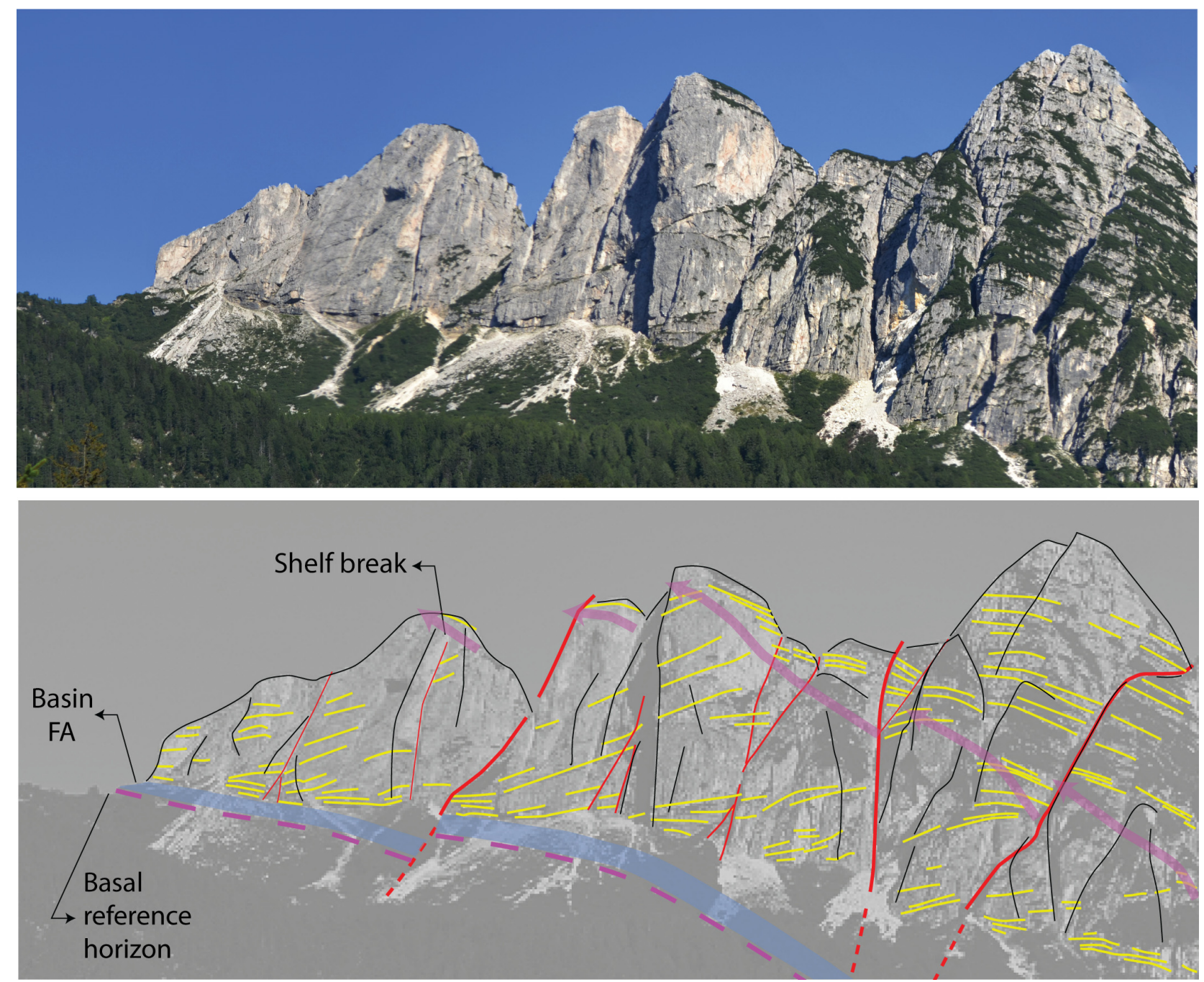

Fig. 5. Panoramic view of the margin to slope complex exposed on the western side of M. Guarda. Despite the original strata having been folded monoclinally and displaced by strike-slip faults, the original geometries are already easily recognizable. The almost massive margin facies of Dolomia Principale connects outer to inner platform deposits (right) to slope clinostratified layers, in turn interfingering northward with thin-bedded basinal limestones. As schematized below, the shelf break trajectory shows a main strong progradation belonging to the second stage of platform evolution.

(especially in the Tamar valley section and M. Privat area). Fine carbonate was probably derived from inner platform environments, because calcareous plankton was not yet dominant in the upper Carnian (Preto et al., 2012). Indistinct horizontal lamination is locally present (facies A2; Table 1) and indicates an absence of bioturbation. This facies association is observed north of a WNW to ESE-oriented belt, from the Sompdogna pass (upper Dogna Valley) to the Tamar valley.

\section{Facies Association 2 (FA2)}

Thin-bedded wackestone/packstone and grainstone layers (facies A4; Table 1), sometimes dolomitized, represent the most common lithofacies of the Carnitza Formation, and usually alternate with FA1 in the middle to lower part of the unit. Grains include pelagic bioclasts, micritic intraclasts and resedimented material (Fig. 6D) probably derived from reefal carbonates of the neighbouring carbonate platform (among which encrusting microproblematica and Tubiphytes are common). Normal grading is sometimes observed as well as planar lamination, and when combined with the slightly lenticular shape of coarser beds allows for the interpretation of fine calcarenites as distal turbidites (facies A4; Table 1). Thick-bedded, often 


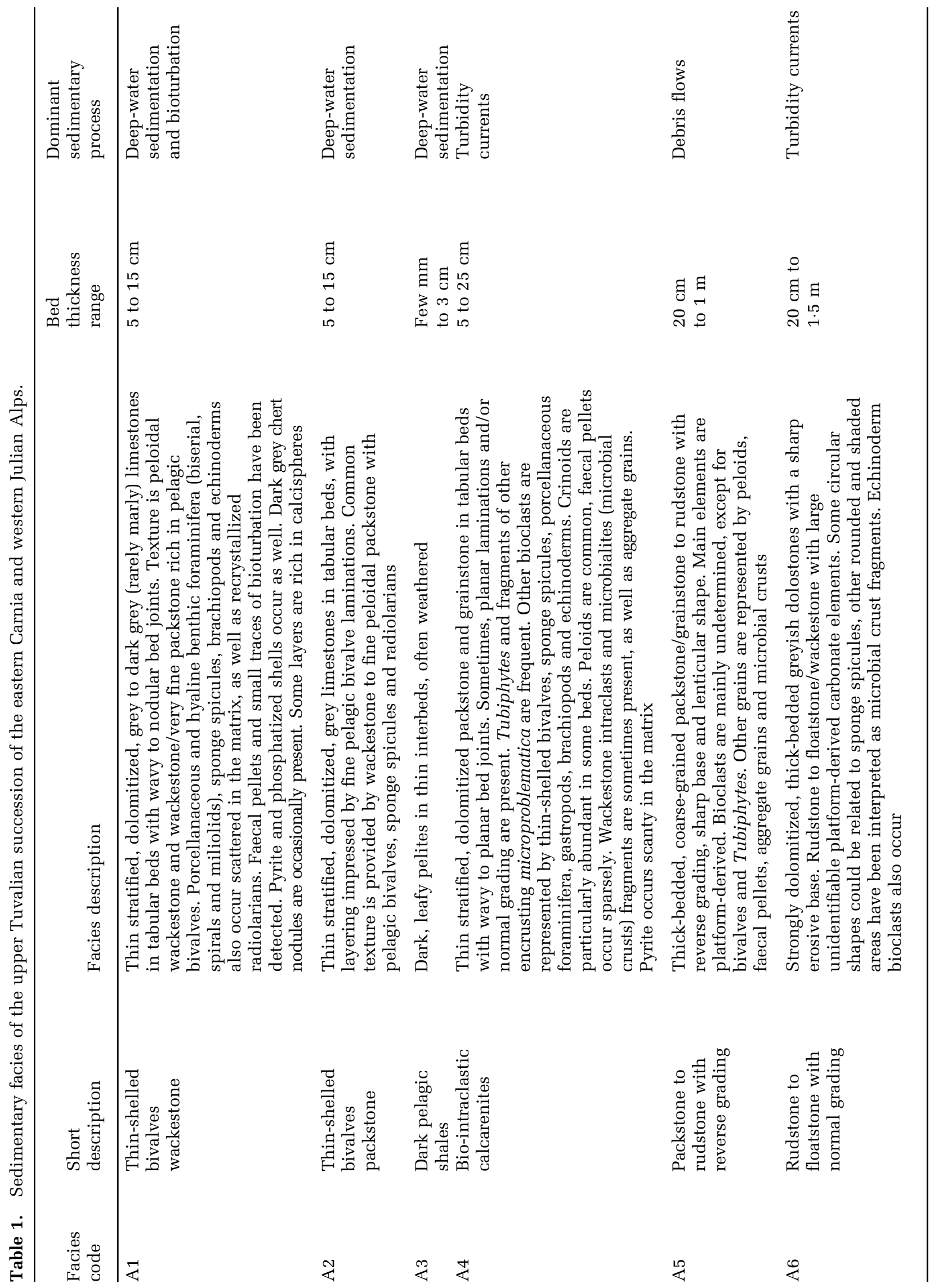




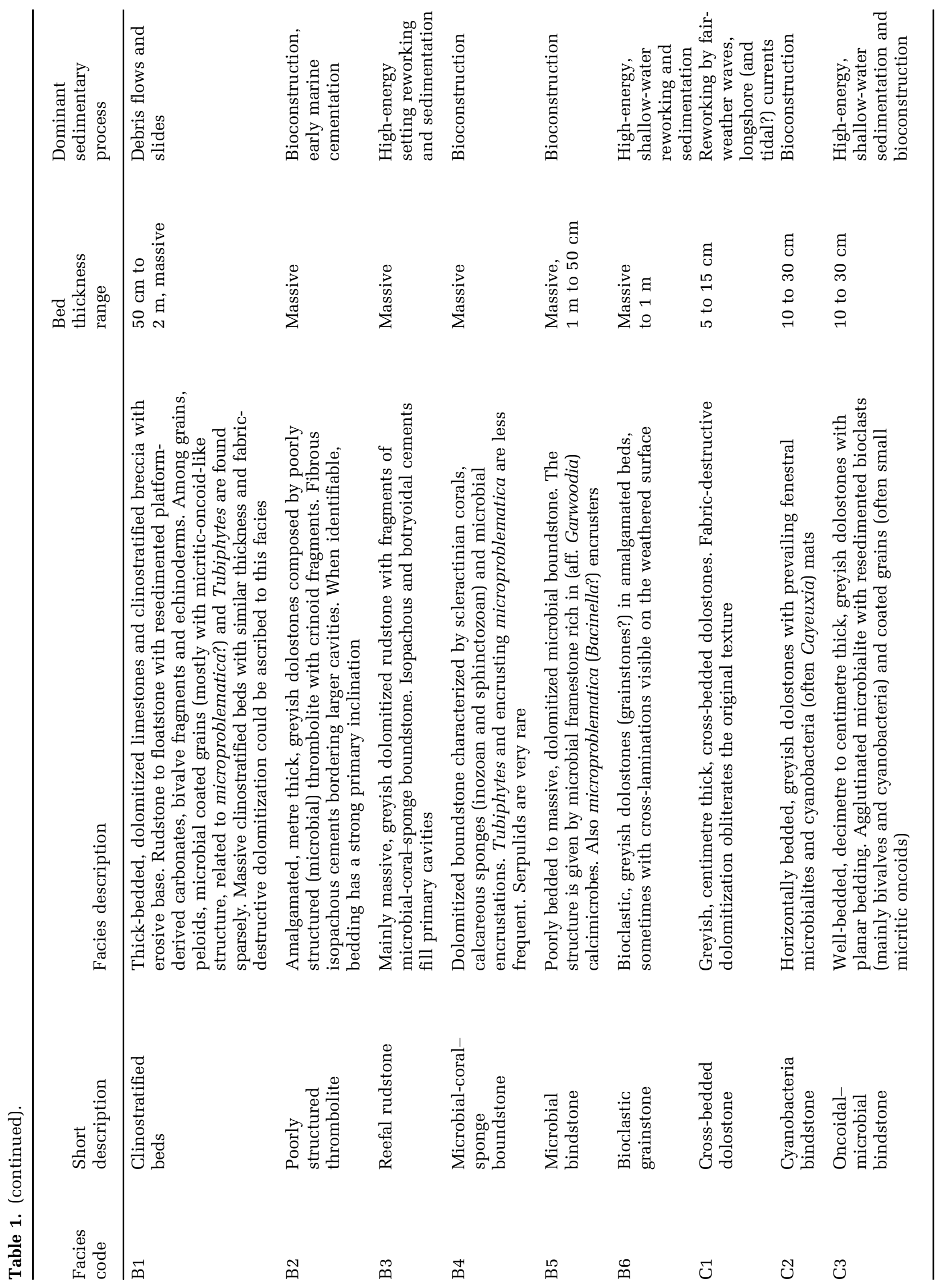




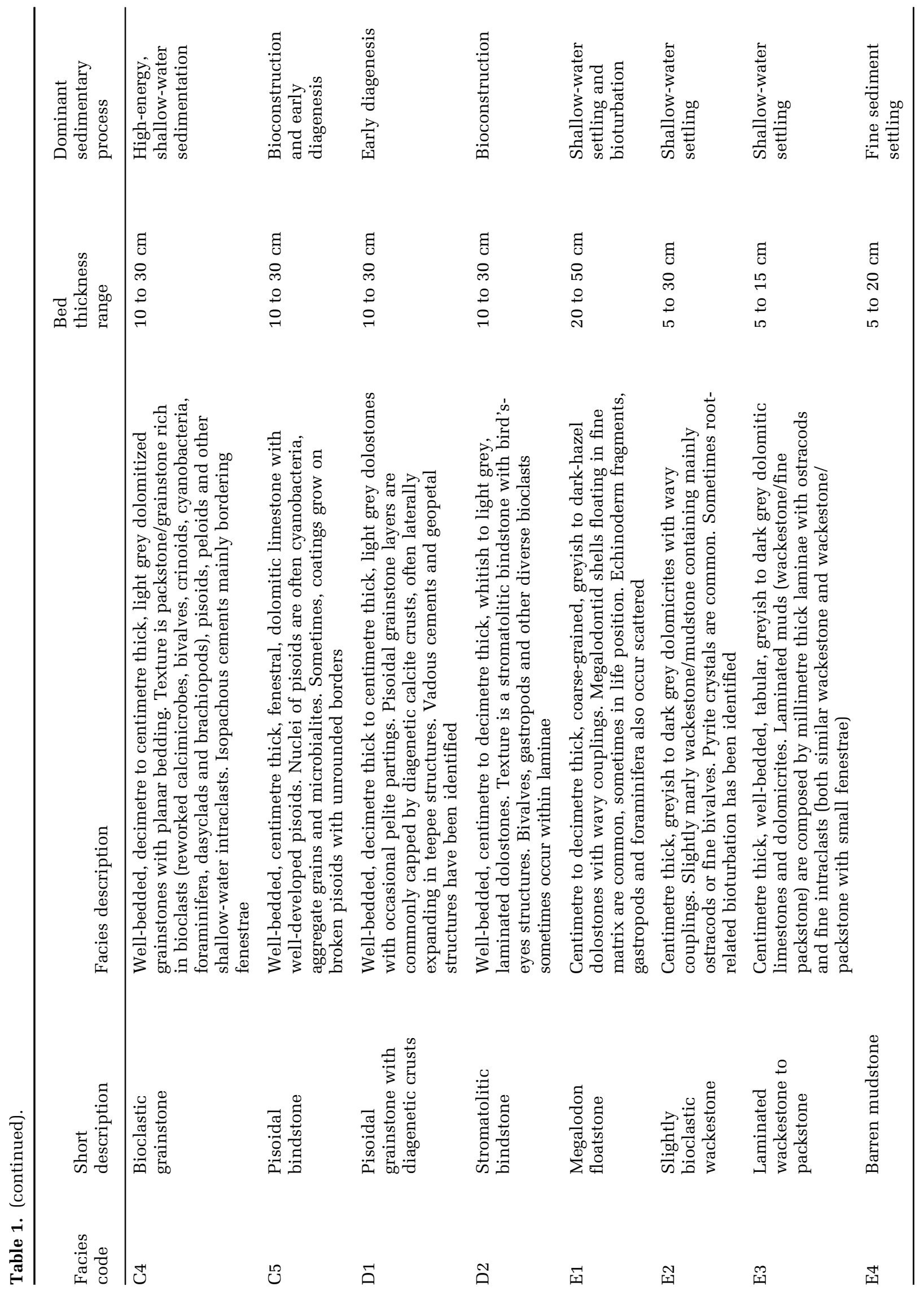




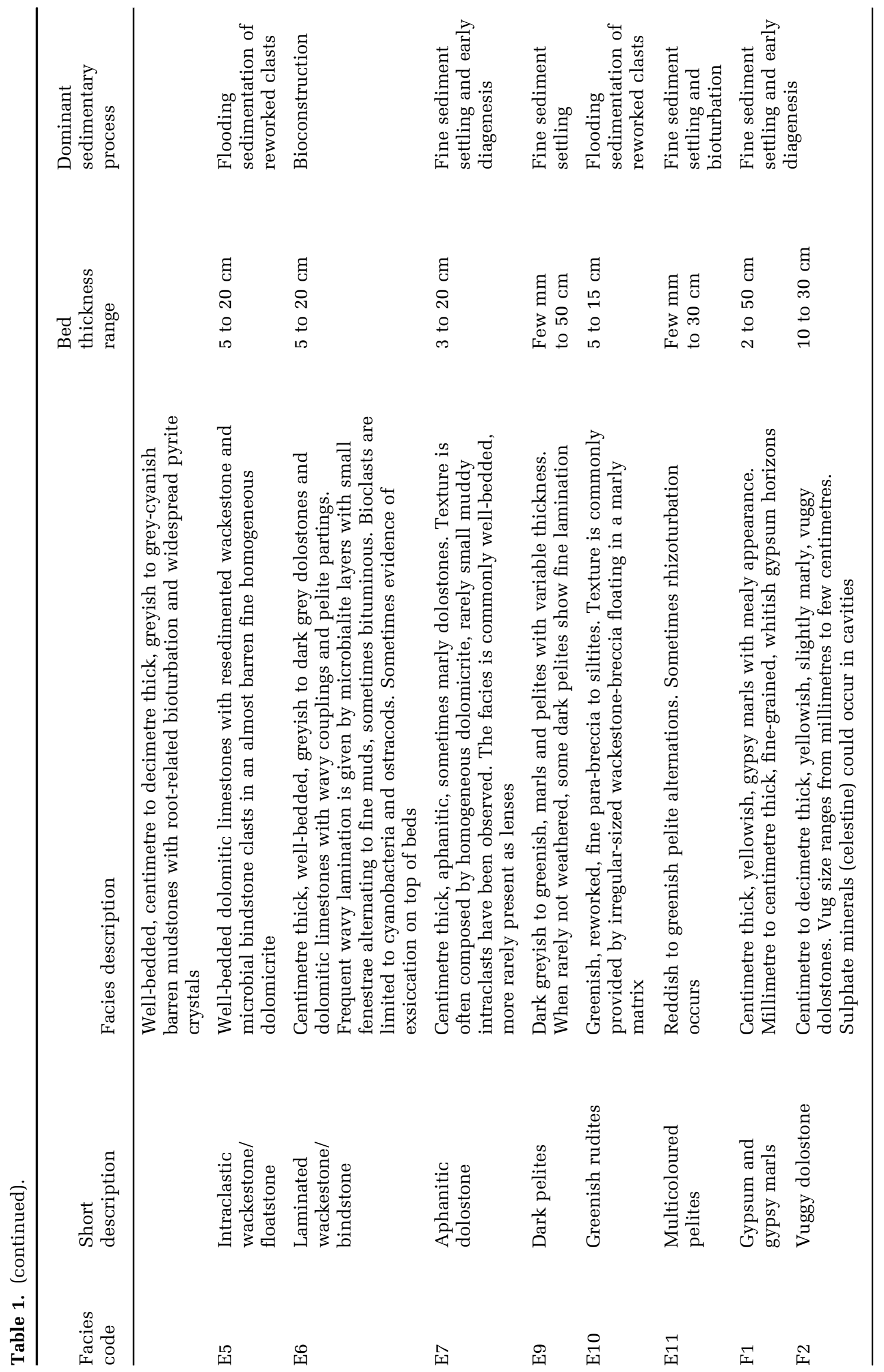

(C) 2017 The Authors. Sedimentology (C) 2017 International Association of Sedimentologists, Sedimentology, 65, 1097-1131 
dolomitized limestones are a recurring facies in the upper part of the Carnitza Formation, and their occurrence is usually accompanied by an increase of grain size with respect to the aforementioned lithofacies. Platform-derived grains are abundant (facies A5 and A6; Table 1); fragments of encrusting organisms and microbialites, coated and aggregate grains, gastropods and benthic foraminifera are present (Fig. 6D to F). Lensshaped beds with erosive bases are often associated with normal grading and planar laminations, and have been interpreted as calciturbidites in a proximal periplatform basin (facies A6; Table 1). Successions of the Carnitza Formation with facies A6 are adjacent to slope clinoforms at Sella Ursic (Figs 5 and 7A), Sella delle Cave, Sella Prasnig and Sompdogna. Packstone to rudstone layers (facies A5; Table 1) characterized by large clasts floating in a sandy to muddy matrix may be instead related to debris flows in the same proximal basin environment. Thin-bedded and relatively fine-grained grainstones are less frequent in the upper part, occurring mainly as intercalations and sometimes characterized by a relative abundance in crinoid fragments (facies A4; Table 1). Slumping affecting thinner beds is rarely observed.

\section{Slope}

Facies Association 3 (FA3)

The previously described facies association laterally interfingers with clinostratified breccia bodies (facies B1; Table 1), commonly ascribed to the Dolomia Principale (Assereto et al., 1968; Gianolla et al., 2003). Strata normally show erosive bases (Fig. 7A), clast size ranges from very fine pebbles to boulders, but strong dolomitization prevents the identification of internal texture and composition of grains. Only in rare beds are grains recognizable, being platformderived intraclasts and bioclasts. Coarse-grained breccia clinobeds are interpreted to be deposited in a lower slope setting. The estimated original dip ranges between $30^{\circ}$ and $35^{\circ}$ (Fig. 5) and is consistent with the angle of repose of gravel.

\section{Facies Association 4 (FA4)}

Clinostratified dolostone banks gradually become amalgamated moving up-slope where they fade into a massive body (Fig. 5). Thin sections only show fabric-destructive dolomitization patterns. In a few cases, microfacies analysis reveals the occurrence of microbial boundstone with small and large clasts trapped within. Facies analysis and depositional geometries are consistent with an upper slope depositional environment.

\section{Outer platform}

Facies Association 5 (FA5)

The massive dolostone zone of FA4 passes laterally into horizontally stratified, metre thick beds. This transition occurs gradually and, where strata are still amalgamated, different facies have been identified, despite the widespread dolomitization (facies B2 to B4; Table 1). Microbial boundstone is the most recurrent texture, with poorly structured thrombolites encrusting bioclasts (mainly crinoid fragments) (facies B2; Table 1; Fig. 7B, D and E) alternated with rudstones composed of clasts (facies B3; Table 1; Fig. 7C) derived from nearby bioconstructions with scleractinian corals (Fig. 7F) and calcareous sponges encrusted by microbialites. From the same lithofacies, serpulid colonies (Fig. 7G) were reported by Gianolla et al. (2003).

Most of the original framework cavities are rimmed by fibrous isopachous cements. This, along with less common botryoidal cement crusts, suggests early marine cementation processes. It is in accordance with a high-energy environment, guaranteeing the intense circulation of fluids necessary for early cementation. A high hydrodynamic setting is also supported by the relative abundance of encrusting, wave-resistant organisms. More gracile forms such as corals and demospongiae are instead found mostly as broken bioclasts.

The massive dolomitized belt (FA4 to FA5) has been identified over a large distance (at least $20 \mathrm{~km}$ ) along strike, from the Cave del Predil area to the Sompdogna pass (upper Dogna Valley), but its inward extension is restricted to a narrow area (10 to $30 \mathrm{~m}$ ) along dip. Facies analysis and stratigraphic location are consistent with its interpretation as a platform margin environment.

\section{Facies Association 6 (FA6)}

Amalgamated massive beds of FA5 laterally split in well-stratified, decimetre to centimetre thick dolostones showing a great variety of facies. Transition frequently occurs by means of amalgamated bioclastic calcarenites showing crosslamination (facies B6; Table 1; Gianolla et al., 2003). A few dozens of metres inward, bedding becomes more evident and decimetre thick bioclastic grainstones alternate with microbialites forming fenestral bindstones (facies B5 and C2; Table 1; Fig. 8A), with abundant 
Table 2. Summary of facies associations and relative inferred palaeoenvironments of the upper Tuvalian depositional system. Stratigraphic sections in which they have been recognized are indicated.

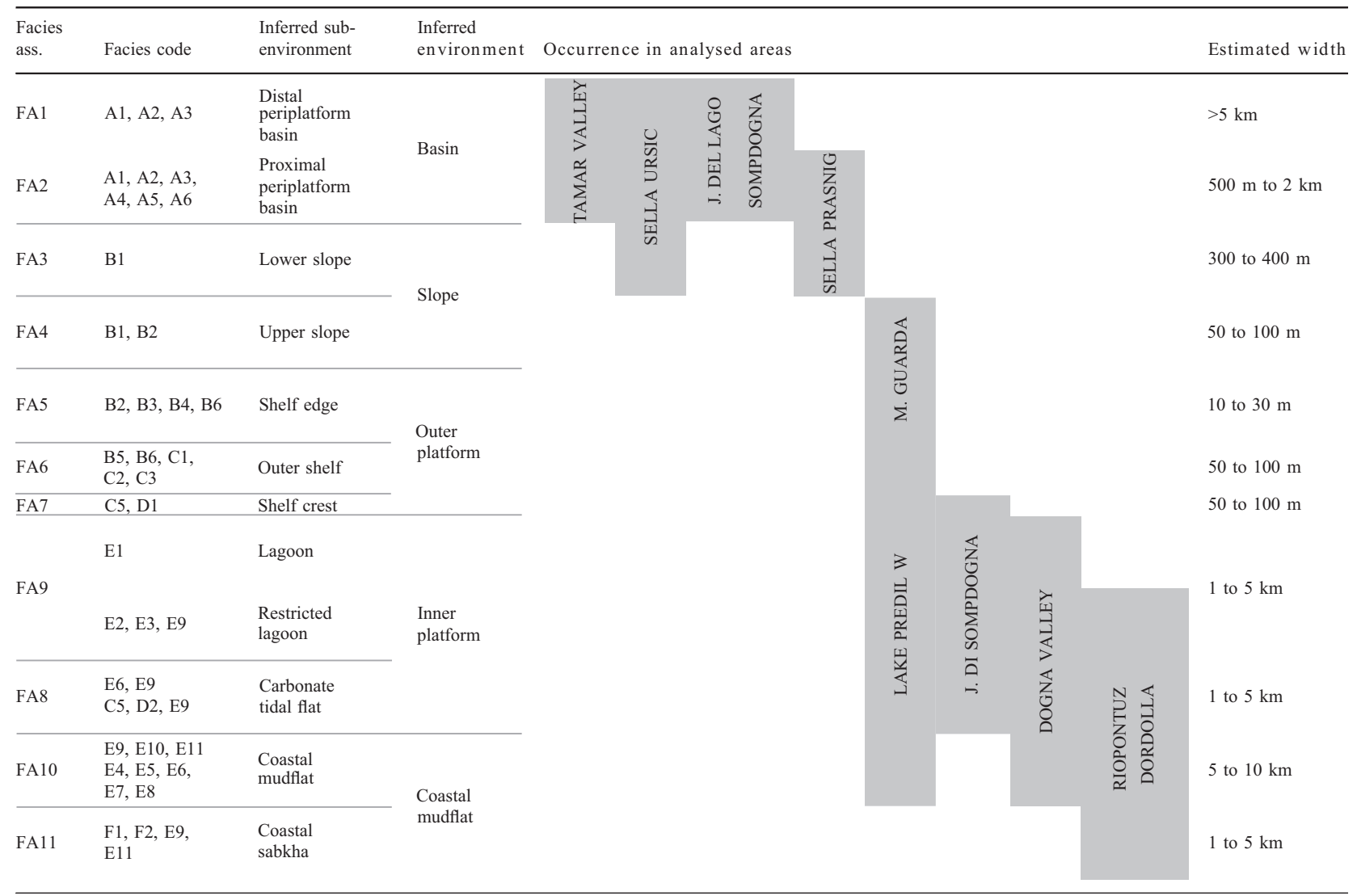

microproblematica and calcimicrobes (primarily Cayeuxia sp.); alternatively, they form agglutinated stromatolites fixing resedimented bioclasts (mainly microbial or cyanobacterial fragments) and small oncoids (facies C3; Table 1; Fig. 8B). Intraclasts of this facies have been found together with bioclasts, resedimented pisoids and peloids within dolomitized grainstones (facies C4; Table 1; Fig. 8C). Some of these layers exhibit predominance of pisoids and cyanobacterial fragments. Fenestrae are lined by isopachous cements.

Locally, metre-scale sets of cross-bedded dolostones have been found (facies C1; Table 1), interrupting the previously mentioned alternations. Although dolomitization prevents detailed observation of the original texture, they are probably related to primarily bioclastic grainstones.

The described features point again to a highenergy environment, probably in the shallow subtidal-intertidal zone, where loose sediment was subject to wave reworking and only encrusting biota were able to form flattened bioconstructions. The same high-energy environment can lead to the development of micritic oncoids. Intraclasts removed from this zone by waves, also accumulated in the toe of the slope deposits (FA2). Facies analysis and stratigraphic location of this facies association are consistent with deposition in an outer shelf environment.

\section{Facies Association 7 (FA7)}

Well-developed pisoids have been found commonly in fenestral dolostones (facies C5; Table 1; Fig. 8D) or in grainstone layers, often capped by cement crusts and sometimes with thin, millimetre thick pelite partings (facies D1; Table 1). Nuclei of pisoids consist both of fragments of FA6 bindstones and of coated and aggregate grains, as well as of broken pisoids (Fig. 8E). Microstalactite and meniscus cements are common features of this facies association. Moreover, tepee structures affecting these beds have been observed (Gianolla et al., 2003). Facies patterns are clearly related to a shallower (mostly supratidal) setting with respect to FA6. Physical correlations allowed location of the depicted facies association relatively close to the shelf break, 

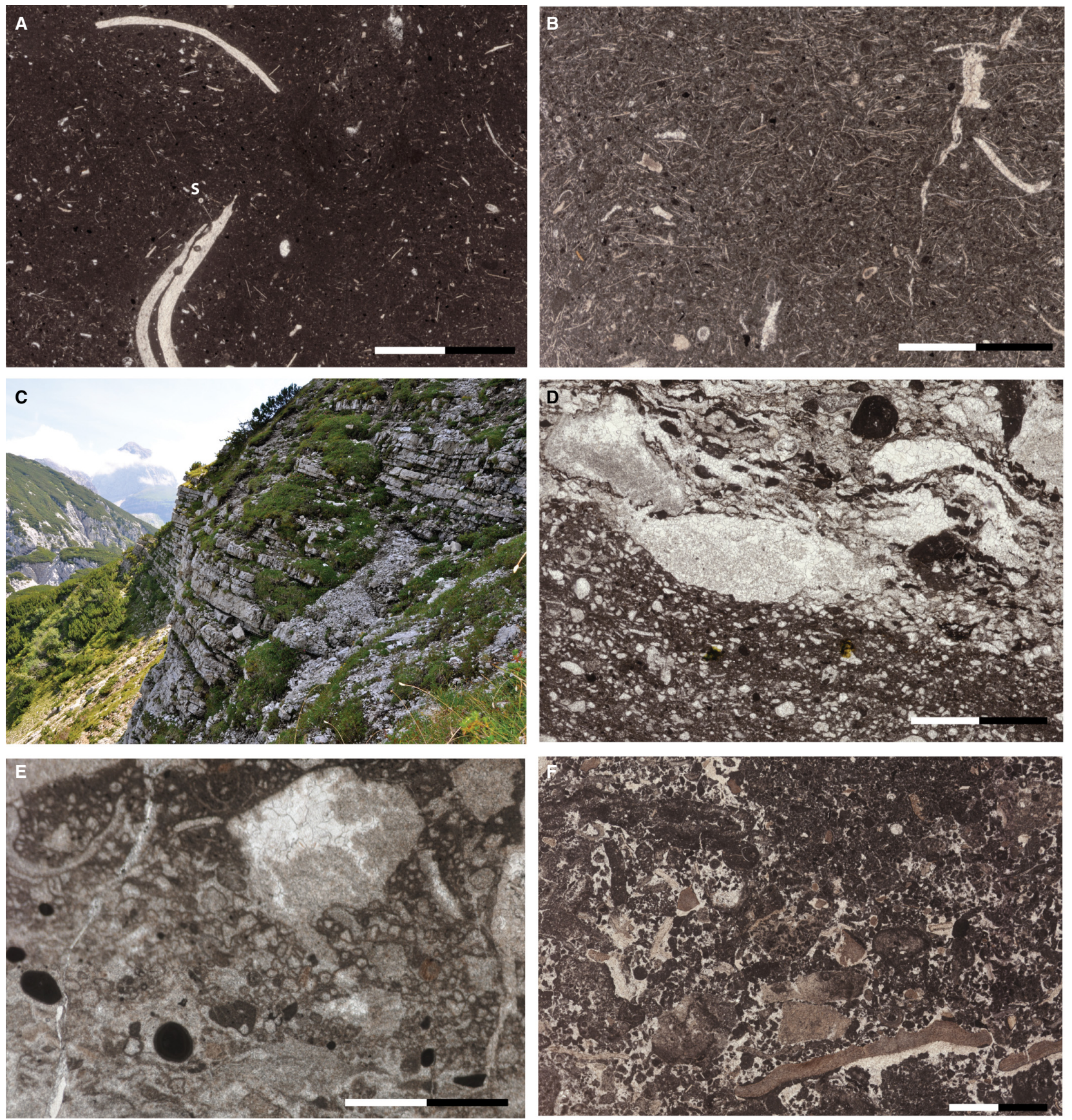

Fig. 6. Microfacies and macrofacies of the upper Tuvalian periplatform basin (FA1 and FA2). Scale bar is $2 \mathrm{~mm}$. (A) Bioturbated bioclastic wackestone (facies A1) with pelagic bivalves, brachiopods, foraminifera, sponge spicules (S) and peloids. Small pyrite crystals are scattered in the matrix (Sella Ursic section, lower part). (B) Fine pelagic wackestone/packstone (facies A2) rich in small bivalves maintaining their original depositional orientation (Sella Ursic section, lower part). (C) Outcrop of the middle part of the Carnitza Formation near Sella Ursic; bedding is enhanced by thin pelite interbeds of facies A3. (D) Transition from bioclastic wackestone/packstone to rudstone/grainstone (facies A5) rich in platform-resedimented elements; most of them have been strongly diagenetically affected and are unclassifiable, with the exception of Tubiphytes and microbial crusts (Sella Ursic section, middle part). (E) Dolomitized rudstone/grainstone to floatstone (facies A6) with carbonate clasts shed from the nearby platform; note the small micritic coated grains, probably resedimented from the outer platform (Sella Prasnig section, uppermost part). (F) Peloidal packstone-rudstone rich in echinoderm fragments and faecal pellets (facies A4) recovered a few metres below erosive clinobeds (near Sella Prasnig). 
few dozens of metres behind it. Pisoids from this belt were reworked both inward and/or outward by stronger storm events, and subsequently sedimented as bio-intraclastic grainstones or fixed by intersupratidal stromatolites. Facies analysis and stratigraphic locations are consistent with the interpretation of this facies association as deposited in a shelf crest environment.

\section{Inner platform}

Facies Association 8 (FA8)

Moving inward, well-bedded dolostones with bird's-eye structures and agglutinated stromatolites (Fig. 8F) trapping diverse bioclasts have been found, often in association with pisoidal dolostones (facies C5; Table 1), with bedding frequently enhanced by millimetre to centimetre thick pelite partings. More commonly, stromatolitic dolostones are composed of alternations of microbial choppy levels with small fenestrae and thin muddy, often organic-rich layers, trapping only ostracods and cyanobacteria (Cayeuxia sp.) bioclasts (facies E6; Table 1; Fig. 9A and B). Stromatolites with cyanobacteria and ostracods take the place of pisoidal beds, while dark pelite interbeds increase in number and thickness.

This facies association probably reflects sedimentation in a carbonate tidal flat, mostly in the intertidal to supratidal setting, even if in some cases stromatolites with isopachous cements filling small fenestrae have been related to a shallow subtidal environment (Roghi \& Dalla Vecchia, 1997). Pisoid intercalations are related to the proximity of this environment to the shelf crest, from where grains were resedimented inward by occasional storm events. Pelites derived from an inner coastal mudflat.

\section{Facies Association 9 (FA9)}

Dark to greenish pelite layers have been found alternating to well-stratified, centimetre to decimetre thick dolomicrites and dolomitic limestones with wavy bed joints (Table 1, facies E2 and E3). Bioclasts are limited to ostracods, small bivalves and brachiopods (Fig. 9C), both enclosed within terrigenous and carbonate beds (De Marco et al., 2000). In the latter case, they have been found with small muddy intraclasts forming thin laminae, or sparse in a micritic matrix together with scattered pyrite crystals (Fig. 9D). Root-related pedoturbation, mud cracks and reptile tracks (Avanzini et al., 2007) occur on top of some beds.
The start-up of the D.P. carbonate platform

More rarely, thick-bedded, crypto-crystalline dolostones with megalodontid (bivalve) internal moulds (facies E1; Table 1; Fig. 9E) are present. In places, echinoderm fragments, gastropods and foraminifera are scattered in a matrix that could have originally been peloidal micrite.

Fine textures indicate a relatively quiet subtidal environment, protected from open marine wave action. However, the relative abundance of laminated muds and layers with poorly diversified fauna points to stressing conditions, probably related to restricted circulation in a shallow subtidal setting, with occasional exposure. Dark pelites derive from an inner siliciclastic coastal mudflat (FA10). On the whole, facies analysis and stratigraphic location allow this facies association to be interpreted as recording deposition in a restricted lagoon environment.

\section{Coastal mudflat}

Facies Association 10 (FA10)

Thick marl and pelite layers (facies E9 to E11; Table 1), sometimes forming metre thick horizons with thin dolostone intercalations, alternate cyclically to the previous inner platform facies associations (Fig. 10A and C). Black to greenish pelites are often laminated and without bioclasts, and represent the most recurrent lithofacies. More rarely, decimetre thick, greenish to reddish pelites occur, sometimes with rhizoturbation traces.

Barren, sometimes marly, dolomicrites frequently occur as intercalations (facies E4, E5 and E7; Table 1); fine muds often bear muddy intraclasts or fragments of FA8 stromatolites, more rarely are almost homogeneous and with abundant pyrite (Fig. 9F and G). Dolomicrites have been found also as carbonate nodules (Fig. 4: Rio Pontuz and Dordolla sections).

Combining sedimentological features, a siliciclastic coastal mudflat environment, connected seaward to an inner platform environment, has been inferred. The colour variation of pelites possibly reflects water table fluctuations and therefore variable oxidation states of $\mathrm{Fe}$ ions, with black and greenish colours related to water-saturated muds (Wright \& Sandler, 1994; Ghosh et al., 2006; Breda \& Preto, 2011). Avanzini et al. (2007) reported a fully continental palynological association for the same lithofacies. Reddish pelites have already been associated with palaeosols by Gianolla et al. (2003) and Carulli et al. (1987). Barren dolomicrites 
1114 M. Caggiati et al.
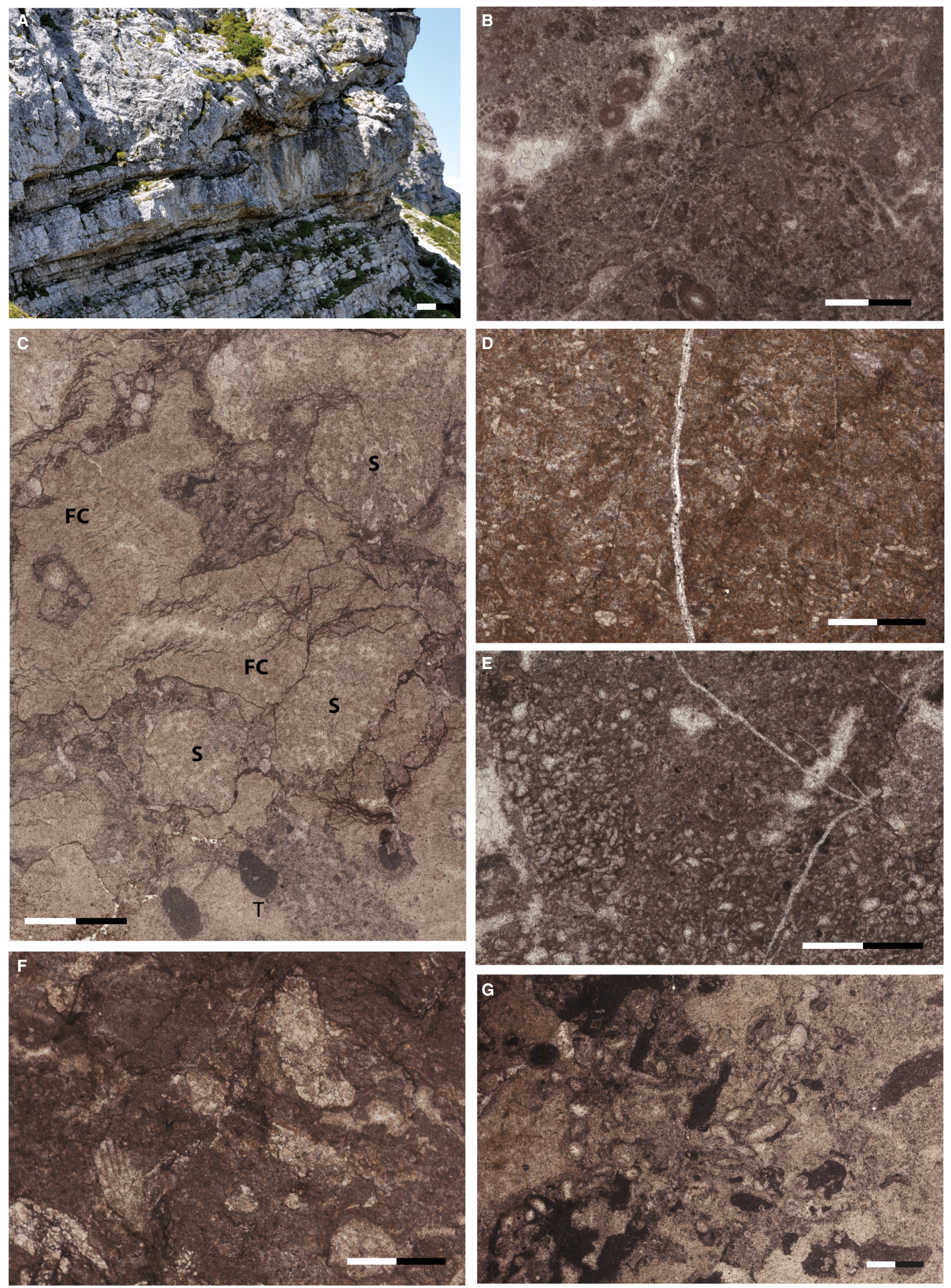

(C) 2017 The Authors. Sedimentology (C) 2017 International Association of Sedimentologists, Sedimentology, 65, 1097-1131 
Fig. 7. Microfacies and macrofacies of the upper Tuvalian upper slope to shelf-edge area (FA4 and FA5). Scale bar is $2 \mathrm{~m}$ in (A) and $2 \mathrm{~mm}$ in (B) to (G). (A) Thick Dolomia Principale clinobeds (facies B1) interfingered to wellbedded dolomitized limestones of the Carnitza Formation cropping out close to Sella Ursic. (B) Dolomitized, poorly structured thrombolite bearing echinoderm fragments (facies B2). Isopachous cement rim internal cavities. (C) Dolomitized boundstone (facies B4) with Tubiphytes (T), calcareous sponges (S) and fibrous isopachous cements bordering primary cavities (FC). (D) Massive, dolomitized, microbial boundstone; small circular to elongated shapes have been interpreted as calcimicrobes. (E) Dolomitized, partly fenestral, boundstone with porostromata calcimicrobes and microproblematica (Bacinella-like) encrusters (facies B5). (F) Coral debris (facies B3) enclosed in a dolomitized microbialitic boundstone. On the left, a small cavity is rimmed by isopachous cement. (G) Dolomitized boundstone (facies B4) with Tubiphytes, microbial crusts and circular to elongated shapes related to serpulid (?) worm tubes in Gianolla et al. (2003). Samples (B) to (G) have been recovered from massive facies of Dolomia Principale cropping out laterally to the base of Lake Predil section.

were formed by carbonate sedimentation in shallow coastal ponds, created by sporadic coastal mudflat flooding. Larger grains were possibly scrubbed from subtidal and/or intertidal zones by storm events and afterwards resedimented as siliciclastics.

\section{Facies Association 11 (FA11)}

Evaporitic variations from FA10 have been observed in the westernmost analysed areas; aphanitic dolostones and gypsum-anhydrite lenses or horizons are interbedded with thick pelite layers, sometimes gypsy marls (facies F1; Table 1), together with yellowish vuggy dolostones (facies F2; Table 1; Fig. 10D to F). This facies association probably reflects evaporitic sedimentation in a coastal sabkha environment.

\section{Facies model}

Based on facies associations and inferred depositional environments, a facies model has been outlined in Fig. 11; a platform crest separates the outer platform to slope and basin environments from the inner platform, which is connected landward to a siliciclastic mudflat. In the upper slope to shelf-edge zone, microbialites and encrusting microproblematica along with sponge-metazoan bioconstructions, formed a wave-resistant reef. Larger intraclasts from here were mostly resedimented downslope by gravitational processes. Smaller intraclasts were also reworked into the outer platform zone, where a high-energy hydrodynamic setting prevailed. Carbonate sand and mud were mainly furnished by the platform crest zone and partly by inner platform environments. Outer platform carbonate sands were probably resedimented in the basin by turbidity currents and deposited in the slope apron together with material scrubbed by the shelf-edge and slope. Fine carbonates, together with minor fine siliciclastics from mudflats of the hinterland, were instead most probably distributed on a wide part of the periplatform basin from suspensions of hypopycnal and mesopycnal flows. The inward transition to the shelf-crest zone was characterized by increasing of microbial mats, binding resedimented grains. The more elevated part was often emerged, favouring precipitation of vadose cements, nucleation of marine pisoids and growth of tepee structures. Intraclasts from the shelf crest were resedimented both seaward and inward. Behind the shelf crest, a tidal flat area gently dipping towards the inner lagoon was developed.

The inner platform presents a metre-scale cyclicity (Fig. 12) related to variations in the accommodation space in the lagoon, cyclically filled both by autochthonous carbonate sediment and by fine siliciclastics from the adjacent mudflat. The presence of an often emerged shelf crest ensured protection from waves and the establishment of restricted conditions.

The complete filling of the lagoon allowed the tidal flat to prevail in most of the inner platform, and when most of the carbonate production was cyclically halted, the coastal mudflat eventually prograded on the tidal flat and part of the shelf crest (Fig. 12). During these periods, inner platform carbonate production was limited to small restricted ponds. The local abundance of organic and plant fragments, as well as of root traces, points to a relatively well-vegetated substrate of the coastal mudflat. The source of pelites was a southern alluvial plain, whose related sediments crops out in the southern Julian Alps (Travenanzes Formation; Zanferrari et al., 2013). The sediment carried by rivers during occasional floods was dispersed in terminal splays, leaving only fine-grained material reaching the coastline system. 

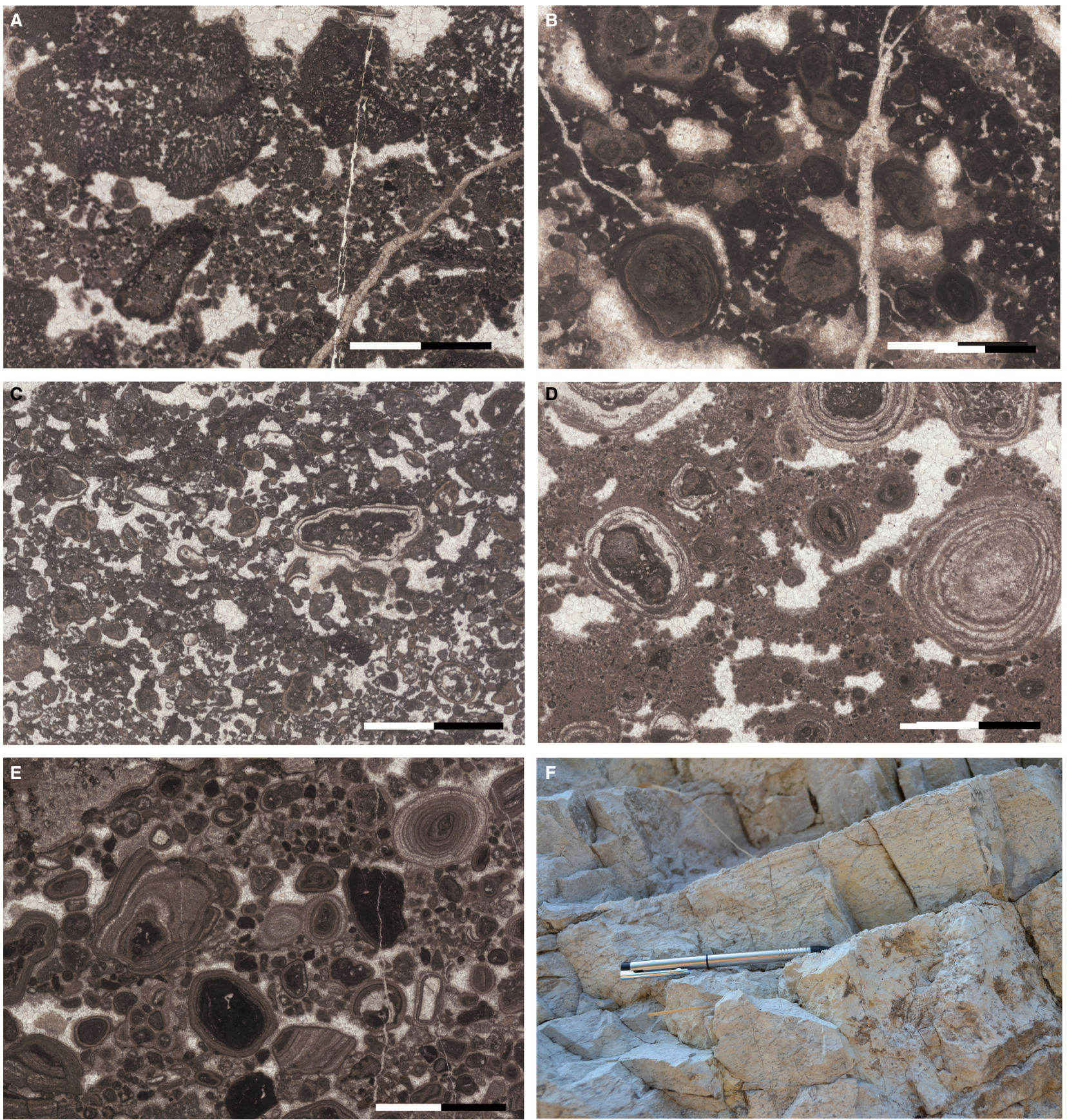

Fig. 8. Microfacies and macrofacies from the upper Tuvalian outer shelf and shelf crest zones (FA6 and FA7), Dolomia Principale, Lake Predil section. Scale bar is $2 \mathrm{~mm}$. (A) Fenestral (microbial) bindstone (facies C2) rich in cyanobacteria (Cayeuxia) both found resedimented (upper part) and in life position (lower right corner). (B) Agglutinated microbialite (facies C3) with resedimented bioclasts, peloids and micritic coated grains (mainly oncoids). (C) Fenestral bioclastic packstone/grainstone (facies C4). Fragments of dasycladacean green algae often occur among larger bioclasts. (D) Fenestral (microbial) bindstone (facies C5) rich in well-developed, small and large pisoids (nuclei are commonly bioclasts, coated and agglutinated grains). (E) Pisoidal, fenestral grainstone (facies D1). Coated grains can be grouped into well-developed, rounded pisoids nucleated on bioclasts or aggregate grains, and poorly-developed pisoids with angular borders, commonly nucleated on former broken pisoids. (F) Well-bedded fenestral dolostone (facies D2). 


\section{Stacking patterns}

Stacking patterns in the investigated sections provide useful information about the evolution of this depositional system in space and time. The stratigraphic sections considered in this work can be split into a group of sections with basinal and slope facies, and a group of sections with platform facies.

For basinal and slope sections, long-term transgressions and regressions are inferred on the base of superposition of facies associations, thickening versus thinning of bedding and grain size (Fig. 4; lower order cycles). Shorter term depositional cycles were also identified, on the basis of bed thickness and grain size only (Fig. 4; higher order cycles).

At the margin, the shelf break trajectory shows at least two main stages: (i) a first stage, where progradation is limited to $c a 250 \mathrm{~m}$, with an aggradation of roughly $200 \mathrm{~m}$; and (ii) a second stage where a reduced aggradation of $100 \mathrm{~m}$ corresponds to a strong progradation of between $2 \mathrm{~km}$ and $4 \mathrm{~km}$ (Figs 3 and 13). In the M. Privat area and Tamar Valley, only basinal strata occur in the Tuvalian, thus setting a limit to the maximum possible progradation of platform clinoforms.

For the platform sections, a long-term transgressive trend is generally observed, which is marked by the gradual transition from the coastal mudflat, sabkha and restricted platform facies of the Travenanzes Formation to the mainly open platform facies of the Dolomia Principale. This overall transgression takes place on thicknesses of hundreds of metres and corresponds to a transgressive phase that appears ubiquitous in the western Tethys (De Zanche et al., 1993; Gianolla et al., 1998; Haas et al., 2012). Shorter term transgressions and regressions that overlap the long-term transgression were identified on the basis of facies superposition and the stacking pattern of peritidal cycles, as described in this section (Fig. 4).

\section{Basin and slope sections}

The Sella Ursic section (section 7 in Fig. 4) has been already presented in Gianolla et al. (2003) and can be split into two parts. The sharp transition from the massive dolostone of the Portella dolomite to the well-bedded limestones of the Carnitza Formation is marked by a sudden decrease in grain size and bed thickness, and by the appearance of pelite intercalations. The first metres of the Carnitza Formation are
The start-up of the D.P. carbonate platform

1117

characterized by the occurrence of FA2 and FA1, with the latter gradually prevailing upward. The thinning-upward trend culminates in a condensed, ammonoid-rich interval. The presence of ammonoid and conodont fossils places the lower Carnitza Formation in the subbullatus ammonoid zone, and the condensed thin pelagic layers to the spinosus ammonoid zone (Lieberman, 1978; De Zanche et al., 2000; Gianolla et al., 2003). Above, a thickening/coarsening upward trend is characterized by the gradual increase of FA2 and then by the overlap of FA3 clinobeds, that constitute the top of the Sella Ursic section. The thickening/coarsening upward interval is physically correlated with a strong progradation of the carbonate platform (Fig. 3A). In more detail, the whole section can be further subdivided into shorter (metre to decametre) coarsening/thickening upward sedimentary cycles, probably related to minor episodes of platform progradation.

In the Tamar valley (section 8 in Fig. 4), above the Portella dolomite, well-bedded dolomicrites of the Carnitza Formation crop out after a $10 \mathrm{~m}$ long covered interval; they show a dominance of facies association FA1 for almost the entire analysed section. Facies Association 2 has been observed only as intercalations at the base of the outcropping succession and after $c a 50 \mathrm{~m}$, close to the top of the Carnitza Formation, where chert nodules within dolostones become very common. Stacking patterns are therefore difficult to recognize. However, a rough subdivision into three parts has been attempted: a lower, $c a 20 \mathrm{~m}$ thick fining upward interval shifts to a weakly coarsening upward interval which culminates after $53 \mathrm{~m}$; the last part of the Tamar Valley section is characterized by a weakly fining upward interval. Differently from the Sella Ursic section, the cherty dolostones of the Bača Formation imply persisting deep basin sedimentation at Tamar Valley, and establishing a physical correlation to a prograding carbonate platform was not possible. Conodont biostratigraphy (Gale et al., 2015) indicates a general Tuvalian age for the section, and a late Tuvalian age (spinosus zone) for the last $12 \mathrm{~m}$ of the Carnitza Formation.

A subdivision into two parts, based on stacking patterns, can be applied also to the Jof del Lago section (section 6a in Fig. 4). The first part of the section is characterized by a thinning/fining upward trend, a thickening/ coarsening upward interval then follows. Facies Association 2 characterizes both parts, but the uppermost coarser beds can be 

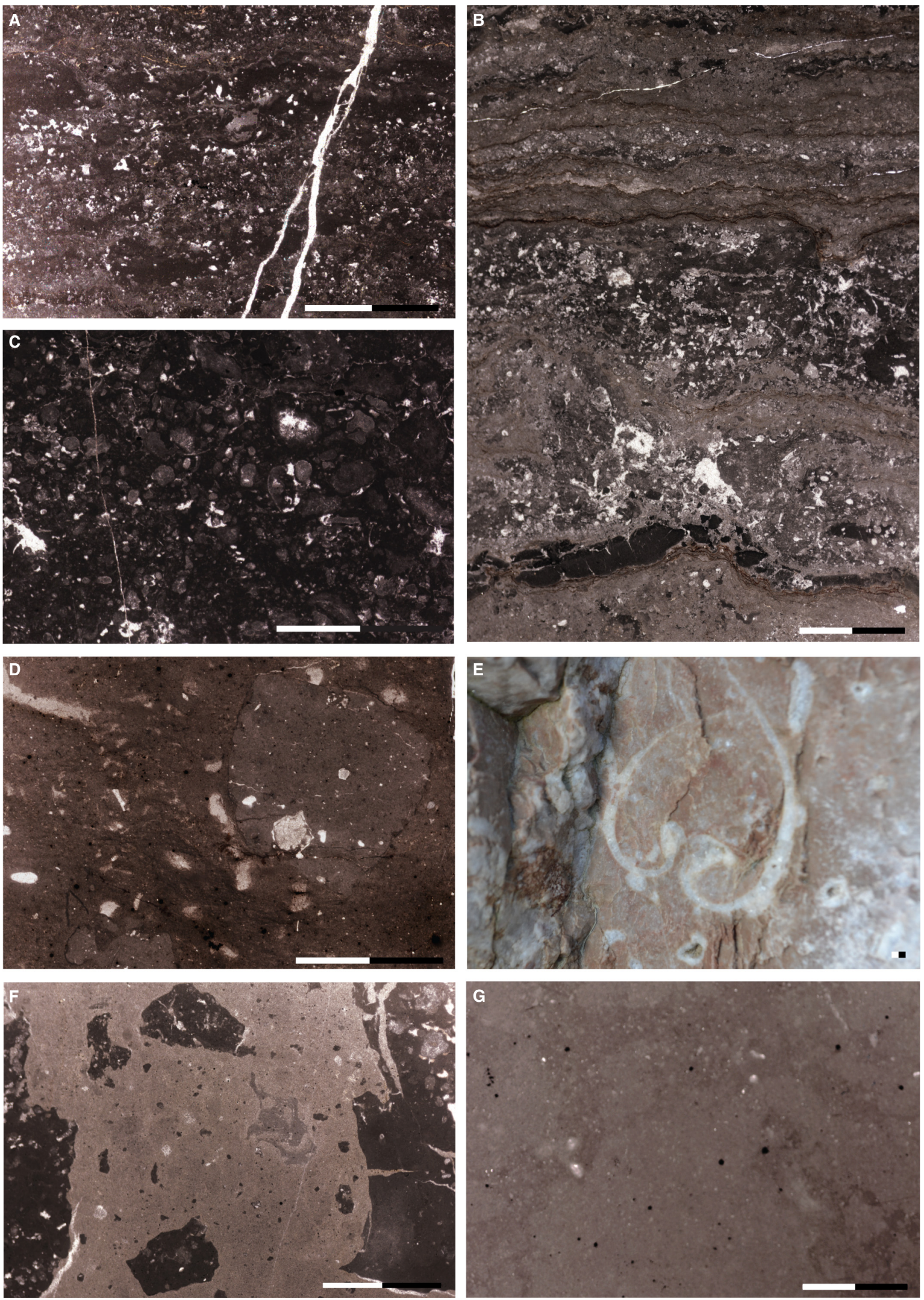
Fig. 9. Microfacies and macrofacies from the upper Tuvalian inner platform system (FA8 and FA9). Scale bar is $2 \mathrm{~mm}$. (A) Laminated, clotted micritic fabric with small fenestrae (facies E6). Bands of (microbial) wackestone alternate with irregular packstone layers. Bioclasts are limited to ostracods (Monticello Member, middle part of Val Dogna section). (B) Microfacies like in (E), alternate with mudstone crusts and are frequently broken. Layering is enhanced by thin clayey brownish horizons (Monticello Member, middle part of Val Dogna section). (C) Peloidal-bioclastic wackestone/packstone with few and small fenestrae (facies E3). Thin bivalves and ostracods prevail among bioclasts. Together with the fenestral texture, the occurrence of irregular fine laminae between the dark matrix suggests the presence of original microbial mats. (Monticello Member, middle part of Val Dogna section). (D) Almost barren, dolomitized wackestone (facies E4) with small fenestrae and widespread pyrite framboids (Dolomia Principale, middle part of Lake Predil section). (E) Thick-bedded floatstone (facies E1) with megalodontid shell showing articulated valves (Monticello Member, lower part of Val Dogna section). (F) Intraclastic floatstone (facies E5) with large mudstone/wackestone clasts floating in a barren dolomicrite (Monticello Member, lower part of Rio Pontuz section). (G) Barren dolomicrite with scattered pyrite crystals and fractures filled by a fine matrix, slightly darker in colour (facies E7). Similar facies have been noted in association with rhizoturbation (Monticello Member, lower part of Val Dogna section).

physically correlated with FA3 clinobeds. In the lower part, the thinning/fining upward trend is interrupted after $c a 13 \mathrm{~m}$ from the base of the Carnitza Formation by a short coarsening upward interval.

In the Sompdogna section (section $4 \mathrm{a}$ in Fig. 4), a short part of the lower Carnitza Formation is characterized by a thinning/fining upward trend and is rich in ammonoids. After ca $7 \mathrm{~m}$, the stacking pattern changes to a thickening/ coarsening upward trend, culminating in downlapping clinoforms. Clinoforms are physically correlated with inner platform beds lying about a hundred metres above the Portella dolomite.

In the Sella Prasnig section (section 5 in Fig. 4), only the upper part of the Carnitza Formation crops out, mostly composed by FA2. Only a general thickening/coarsening upward trend is detectable, capped by the transition to FA3. This trend can be laterally related to a strong platform progradation visible on the left side of the Cime delle Rondini (Fig. 5).

\section{Platform sections}

The Lake Predil W section (section 6b in Fig. 4) starts with massive dolostones of upper slope (FA4) and shelf-edge (FA5) facies associations. After $5 \mathrm{~m}$, well-bedded outer platform facies (FA6 and FA7) appear and bedding gradually becomes more visible. Bindstones alternate with grainstones, and millimetre thick pelite horizons sometimes occur between supratidal dolostones. Approximately $20 \mathrm{~m}$ above the base of the section, intercalations of inner platform facies associations (stromatolitic, intertidal and supratidal dolostones, FA7) appear as metre thick intervals, along with subtidal dolomicrites (FA9) and stromatolites (FA8), multicoloured pelitic palaeosols and aphanitic dolostones (FA10).

The thickness of terrigenous horizons progressively increases upward, whereas FA6 disappears. After $c a 65 \mathrm{~m}$ from the base of the section, only inner platform facies occur and alternate regularly to form peritidal cycles. Facies Association 7 oncoidal-pisoidal calcarenites become rare, and FA10 stromatolite layers become abundant. Almost synchronously, the terrigenous content begins to decrease.

The section is mainly organized in a regressive-transgressive trend. Considering tectonic displacements and physical field relationships, the base of the section lies about $95 \mathrm{~m}$ above the Portella dolomite, whereas its top can be laterally correlated with the base of the section presented in Gianolla et al. (2003), measured on the east side of Lake Predil (Figs 3 and 4) and which is made mostly of beds of FA7 to FA11.

The Jof di Sompdogna section (section $4 \mathrm{~b}$ in Fig. 4) is composed of peritidal cycles made of FA9 thick beds characterizing the subtidal part, and FA8 and FA10 (multicoloured pelites) for the intertidal and supratidal part. It is located stratigraphically hundreds of metres above the clinostratified dolostone of the Sompdogna section (section 4a in Fig. 4), after an interval that was not investigated due to strong tectonic deformation. Based on vertical organization of facies associations, a regressive trend has been observed. As in the last metres of the Lake Predil $\mathrm{W}$ section, the terrigenous component in the supratidal parts is very reduced and disappears upward in the upper part of the section, which was not logged due to accessibility reasons.

In the Dogna Valley (section 3 in Fig. 4), the Portella dolomite is immediately followed by a carbonate-siliciclastic succession, commonly 

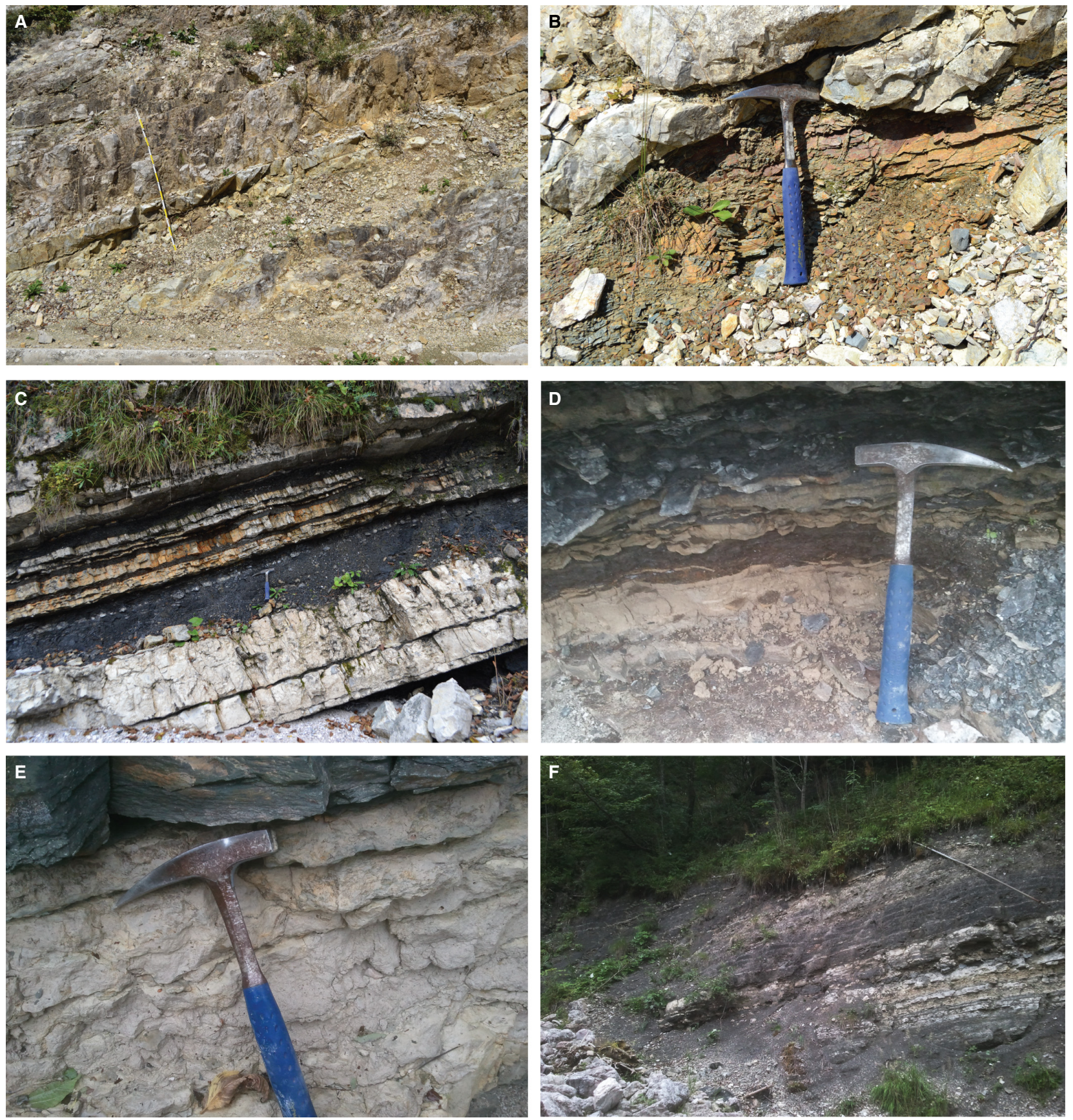

Fig. 10. Macrofacies from the upper Tuvalian inner platform to coastal mudflat system (FA10 and FA11). (A) Metre thick carbonate-siliciclastic cycles (Dolomia Principale) cropping out on the Lake Predil eastern side; greenish and reddish pelites (facies E11) compose thick layers and are sometimes associated with calcrete horizons. (B) Detail of reddish-greenish pelites, interpreted as palaeosols. (C) Metre-scale cycles (Monticello Member) with wellbedded dolostones alternating with dark pelites (facies E9), cropping out on the T. Dogna riverbed. (D) and (E) Reddish pelites and gypsy marl horizons (facies F1) intercalated to greenish laminated pelites (facies E11) cropping out near the Dordolla village (Travenanzes Formation). (F) Vuggy dolostone and gypsum thin beds (facies F1 and F2) interlayered to thick intervals of dark pelites (Travenanzes Formation), same locality as (D) and (E).

ascribed to the Monticello Member. Thick beds of the FA9 open lagoon facies association prevail in the lowermost part, alternating with almost barren dolomicrites. After $c a 10 \mathrm{~m}$, desiccation cracks on bed tops and pelite interlayers appear, together with the occurrence of stromatolitic dolostones (FA8). Upward, dark pelites with dolomicrite intercalations and 


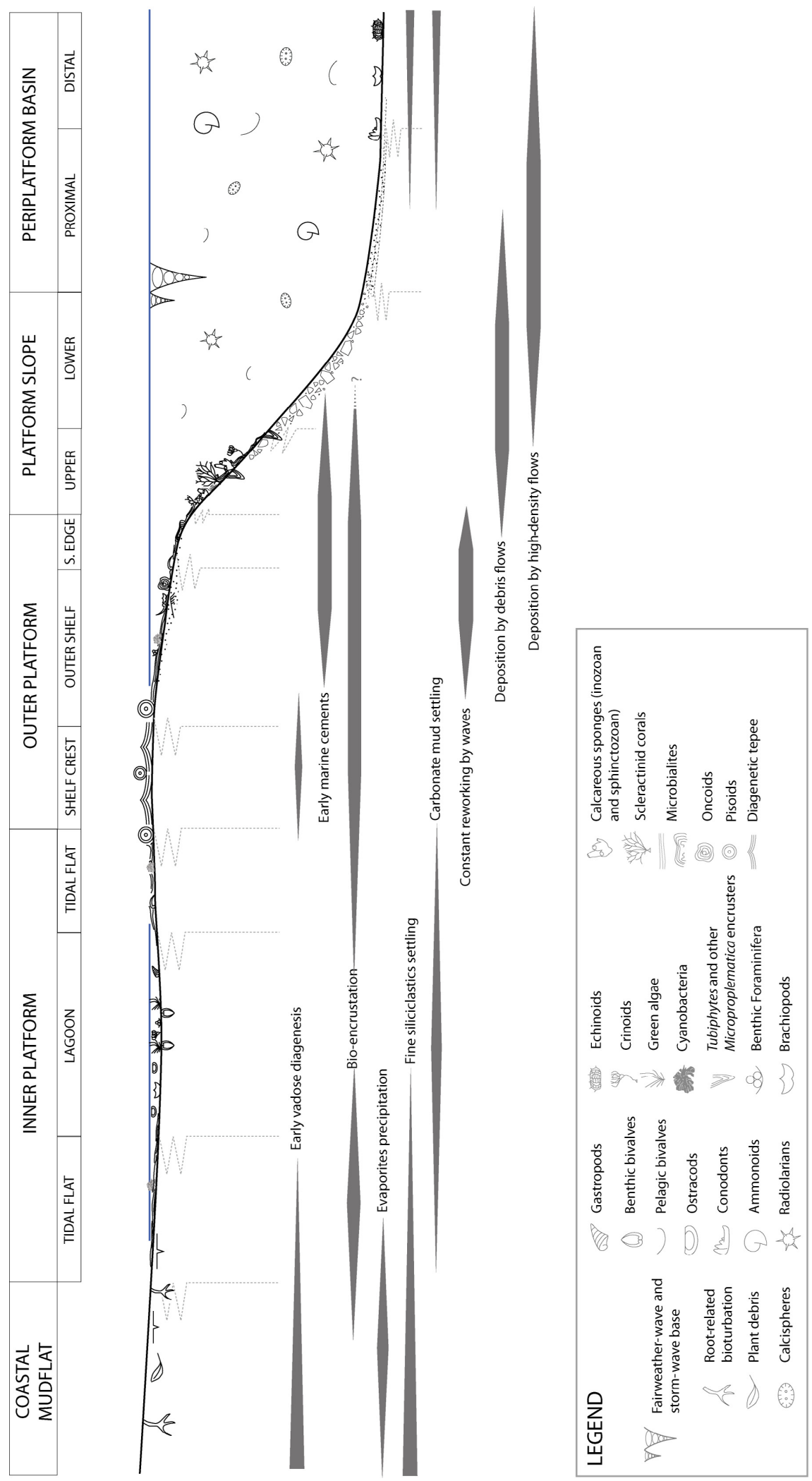

Fig. 11. Generalized depositional model of the early stage of the Dolomia Principale carbonate platform inferred from the investigated stratigraphic sections. Facies associations relative to the illustrated environments are discussed in the text. Below the profile, horizontal grey bars indicate the frequency of main sedimentological processes. Vertical and horizontal distances are not at scale. 


\begin{tabular}{|c|c|c|}
\hline & Distal alluvial plain & Shelf crest \\
\hline & Coastal mudflat & Outer shelf \\
\hline & Coastal ponds (carbonate) & Shelf edge \\
\hline$-\xi$ & Tidal flat & Slope \\
\hline 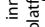 & Inner lagoon & Periplatform basin \\
\hline
\end{tabular}
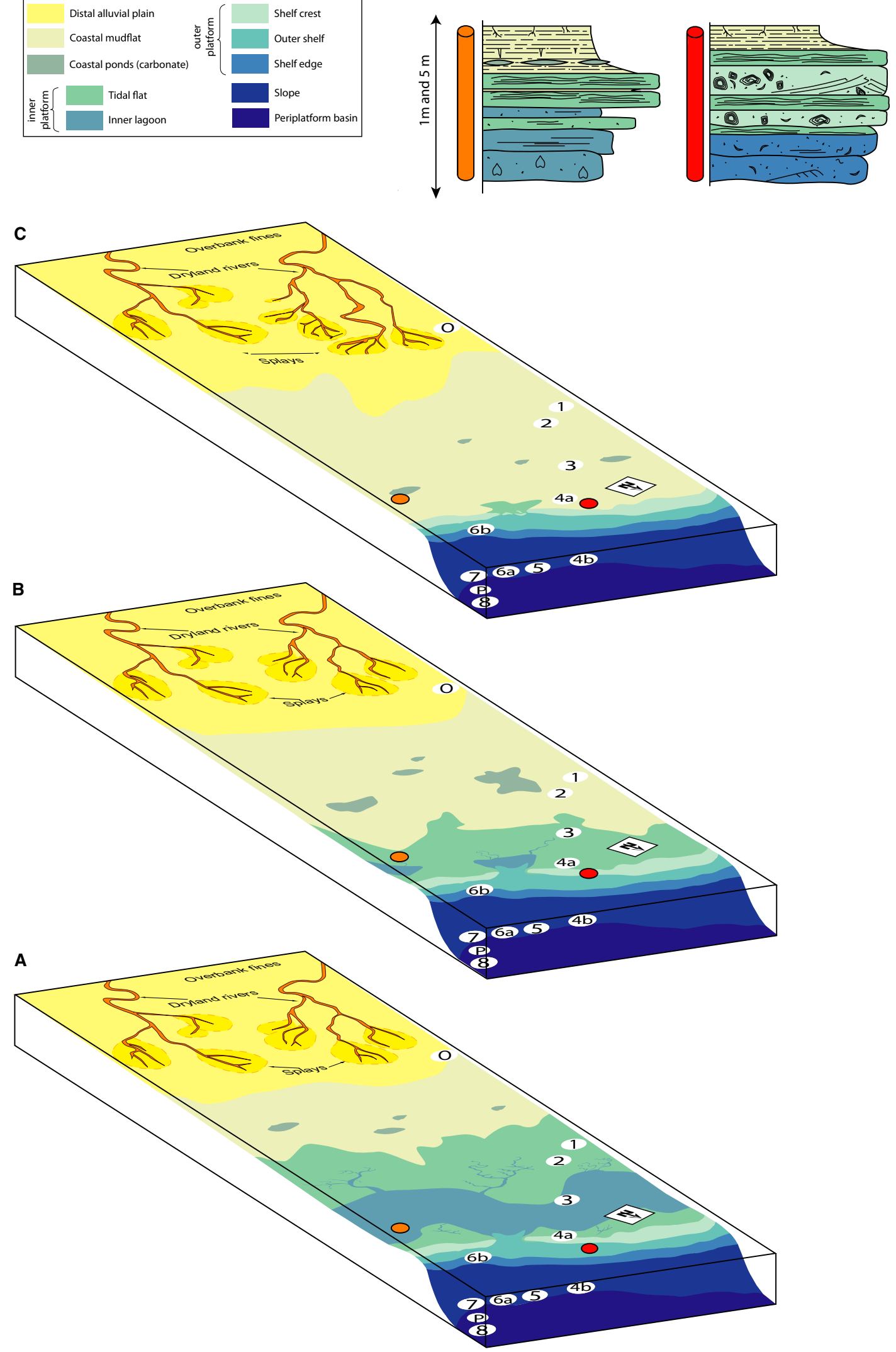


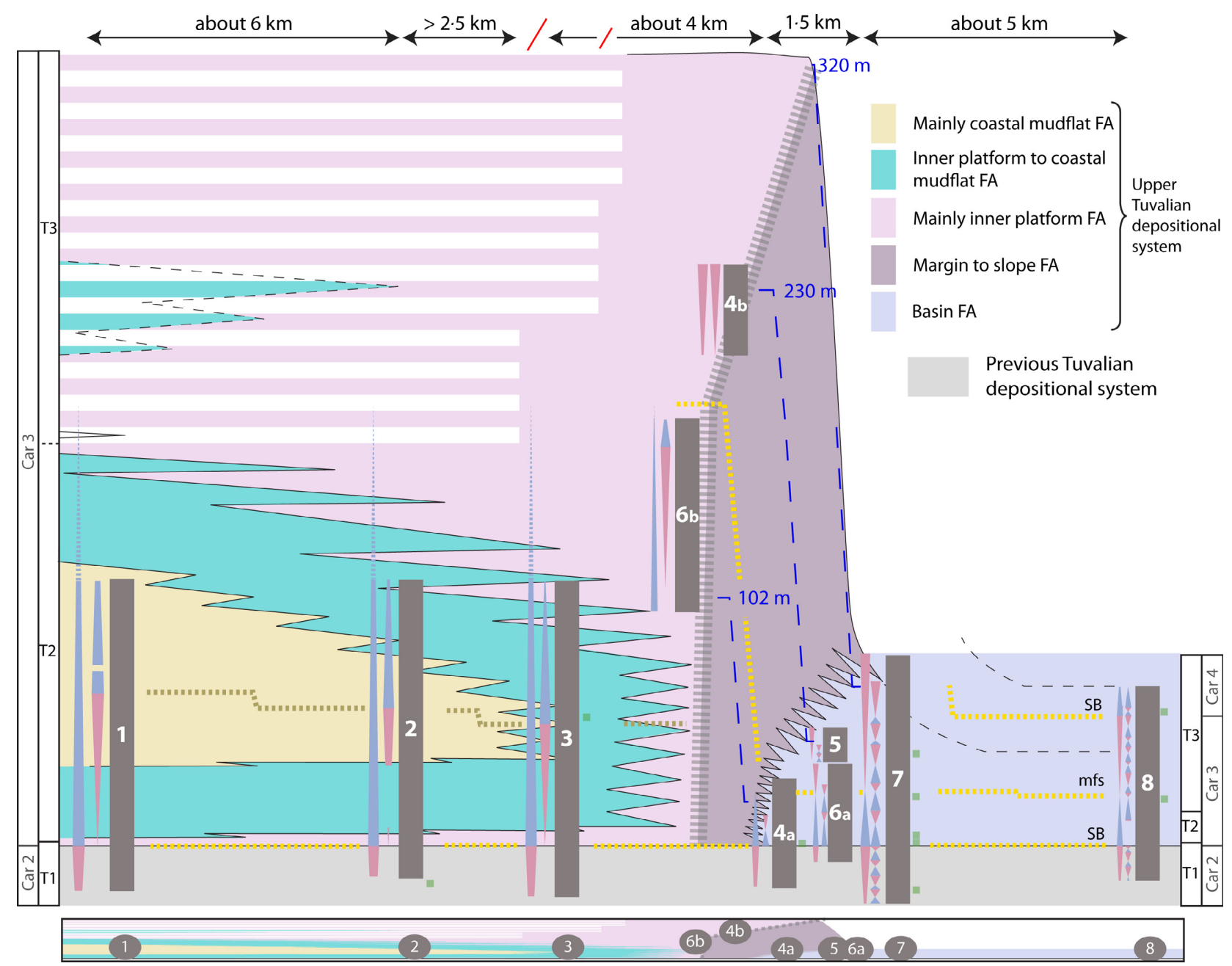

Fig. 13. Correlation scheme of the investigated Upper Carnian succession: sections of Fig. 4 have been plotted at the same scale in their spatial position on a platform-basin profile oriented along dip (vertical scale is exaggerated $50 \times$ ). Below, the same scheme is represented without vertical exaggeration. The thick grey dashed line indicates the platform margin trajectory. Blue dashed lines indicate physical correlations. Yellow and brownish dashed lines refer to sequence stratigraphic correlations. Biostratigraphic data of Fig. 4 are indicated by small green squares. Depositional sequences and biozones are shown laterally - SB, sequence boundaries; mfs, maximum flooding surface. Thick white horizontal lines in the area on the left upper part indicate that this part of the succession has not been analysed in detail in this work.

restricted inner platform facies associations become common, composing metre-scale cycles: the superposition of coastal mudflat facies associations (FA10) to intertidal/subtidal microbialites (FA8 and FA9) is evident, and it is occasionally followed by subtidal dolostone. Traces of subaerial exposure occur frequently, as well as plant fragments. Additionally, reptile footprints and nests have been found (Roghi \& Dalla Vecchia, 1997; Avanzini et al., 2007). The

Fig. 12. Reconstruction of local palaeogeography for the eastern Carnia/western Julian Alps during late Tuvalian. Single shallowing-upward cycles relative to the inner platform (orange spot) and outer platform (red spot) environments are schematically represented. They reflect changes in the distribution of inner platform depositional environments: the shallow lagoon separating the inner tidal flat from the platform crest in (A), is completely filled in (B), with only the tidal flat connecting the margin system to the coastal mudflat. In (C), the inner platform carbonate production is temporarily demised, and the coastal mudflat directly lay close to the margin. Numbers within black spots correspond to those of Fig. 1 and indicate the relative position of analysed sections (' $\mathrm{O}$ ' and ' $\mathrm{P}$ ' correspond to additional sections of Ovedasso and M. Privat). 
facies superposition thus outlines a regressive interval that culminates near the top of the section. From the last metres upward, the thickness and frequency of pelite horizons begin to decrease and at $c a 120 \mathrm{~m}$ from the top of Portella dolomite, pelites completely disappear outlining a transgressive trend. The palynological association from this interval in Dogna Valley indicates an upper Tuvalian age (subbullatusspinosus ammonoid zones; Roghi \& Dalla Vecchia, 1997; Avanzini et al., 2007).

A similar trend is observed also in the western end of the studied area (Rio Pontuz and Dordolla); here, the carbonate-siliciclastic cycles directly lie on the Portella dolomite, indicating the sudden emplacement of inner platform environments. The lower parts of the Rio Pontuz (section 2 in Fig. 4) and Dordolla (section 1 in Fig. 4) sections are characterized by alternations of FA8 to FA10, similar to cycles described for the Dogna Valley section, but with a predominance of laminated muds in the subtidal portion. Plant fragments are common, and slightly bituminous FA8 stromatolites increase upward. A regressive interval occurs $c a 20 \mathrm{~m}$ from the base of the section, outlined by the prevalence of FA10 reddish to greenish pelite horizons with respect to the darker ones, and in few metres, accompanied by the occurrence of evaporitic features (FA11) in both carbonate and terrigenous portions of the cycles. In the Rio Pontuz section, after a covered interval, FA10, FA8 and FA9 alternate to form metre to decametre-scale cycles reflecting shifts from an arid coastal mudflat to a coastal sabkha environment that persists for less than $30 \mathrm{~m}$. Above, FA10, FA8 and FA9 again alternate to form thick peritidal cycles, with the subtidal portion progressively showing features related to less restricted environments (for example, E1 and E2 but with a relatively diversified fauna). In the Dordolla section, the evaporitic interval is thicker and characterized by abundant siliciclastics, with common centimetre thick gypsum interbeds, and carbonates reduced to thin aphanitic dolostone intercalations. Carbonatesiliciclastic cycles similar to those of the basal part occur again at $c a 70 \mathrm{~m}$ upward. Thus, the Dordolla section has a regressive part that ends with the gypsum-rich interval, and the overlying part of the succession is transgressive.

Due to tectonic deformation and recent landslides, the upper part of Monticello Member has not been measured at Dordolla. However, the transition to carbonate peritidal cycles of the Dolomia Principale, characterized by the appearance of laminated, intrabioclastic dolomitic packstone-grainstones, and stromatolites on top of cycles, and the simultaneous strong decrease in siliciclastics (Carulli et al., 1987) can be observed approximately 200 to $250 \mathrm{~m}$ upward, on the east side of upper Aupa valley, south of Dordolla.

\section{DISCUSSION}

\section{Stratigraphic correlations}

Based on biostratigraphy, the depicted depositional system can be wholly framed in the Tuvalian. The Carnitza Formation is dated to the subbullatus ammonoid zone (Tuvalian 2) and at least partially to the spinosus zone (Tuvalian 3) (Lieberman, 1978; De Zanche et al., 2000; Gianolla et al., 2003; Figs 3 and 4).

The age of the Portella dolomite is less clearly constrained and has been considered to belong to the dilleri zone (Tuvalian 1) in Gianolla et al. (2003). Sections have been correlated mainly by physically tracing sedimentary units and marker beds on LIDAR (light detection and ranging; Fig. 3) and considering facies stacking patterns, since significant high-resolution biostratigraphic markers (ammonoids and conodonts) occur only where basinal facies prevail, and are instead substantially missing in carbonate platform successions (where only palynomorph biostratigraphy is available).

The Portella dolomite represents a massive dolomitized body that is always recognizable, maintaining similar thickness and sedimentological features in the entire investigated region. This suggests the development of a flat topography on which the Dolomia Principale platform started up (Figs 4 and 7); in sections located south-west of a roughly WNW-ESE-oriented belt only inner platform facies associations have been found overlapping the dolomitized body. A similar situation has been identified in the Dolomites (Breda \& Preto, 2011) and Eastern Carnia (Zanferrari et al., 2013), where fine siliciclastic and dolostone alternations of the Travenanzes Formation sharply overlie well-bedded Tuvalian dolostones of the Heiligkreuz Formation (Lagazuoi Member). The latter has been correlated with the Portella dolomite by many authors (De Zanche et al., 2000; Gianolla et al., 2003; Preto et al., 2005). However, while in the Dolomites palaeokarsts occur on top of the Lagazuoi Member (De Zanche et al., 1993; Breda et al., 2009), 
in the study area no evidence of subaerial exposure was found.

In sections located north-east of the WNWESE-oriented belt, the top of the Portella dolomite is directly overlapped by basinal facies of the Carnitza Formation (sections $4 \mathrm{a}$ to 8 in Figs 4 and 7), marking a drowning unconformity. In these basinal sections, a $c a 20 \mathrm{~m}$ thick thinning/fining upward trend is observed, above the drowning unconformity. The level on top, in the inner platform facies, physically correlates roughly $200 \mathrm{~m}$ above the top of Portella dolomite. The thinning/fining upward interval has been interpreted at Sella Ursic as the transgressive systems tract (TST) of depositional sequence No 1 (Car 3 in Stefani et al., 2010) by Gianolla et al. (2003), and the maximum flooding surface ( $\mathrm{mfs}$ ) has been placed at the condensed horizon dated at the transition from the subbullatus to spinosus ammonoid zones.

At Sompdogna, $>10 \mathrm{~m}$ of thinning/fining upward beds of Carnitza Formation are present, and the whole basinal succession correlates with the lower $c a 100 \mathrm{~m}$ of inner platform facies, i.e. below the maximum flooding surface. The Sompdogna section lies very close to the early margin. The interpretation of the current study is that the sedimentary cycle with reduced thickness observed at Sompdogna represents a higher order depositional sequence.

The top of Lake Predil W section correlates with the mfs. The Lake Predil E section of Gianolla et al. (2003) includes the mfs (Fig. 3A), and its upper part corresponds to the strong progradational phase of M. Guarda (Fig. 5) and to the thickening/coarsening upward interval observed in the basinal successions. Based on physical correlations (Fig. 13), the main regressive trend in the Jof di Sompdogna section (section $4 \mathrm{~b}$ ) probably correlates with the upper Lake Predil E section.

In the landward part of the depositional system, complex interactions occurred between the rates of carbonate production, accommodation space creation, and siliciclastic input as determined by climate fluctuations and the proximity of a source area to the south (Brusca et al., 1981; Cati et al., 1987; Gianolla et al., 1998). A lower regressive-transgressive cycle can be easily correlated throughout all platform sections (sections 1 to 3 in Figs $4 \mathrm{~A}$ and 13). The thickness of this inner platform cycle is almost constant $(>100 \mathrm{~m})$ throughout the area, and it lies below a level that has been physically correlated with the $\mathrm{mfs}$ of Sella Ursic, lying roughly $200 \mathrm{~m}$ above the Portella dolomite. Therefore, this cycle should be of a higher frequency (low rank, sensu Catuneanu et al., 2011) with respect to the transgressive-regressive cycle of Sella Ursic, interpreted by Gianolla et al. (2003) as a complete third-order depositional sequence.

\section{Implications on regional palaeogeography}

Interestingly, a similar stratigraphic framework has been observed in the Tuvalian succession of the central Dolomites (Breda \& Preto, 2011), where three main carbonate-siliciclastic cycles occur above a subaerial unconformity on top of the Lagazuoi Member, organized in an overall transgressive pattern. A peculiar feature of the depositional system is that while the coastline is retreating, the carbonate shelf break is aggrading and prograding, as determined by physical and biostratigraphic correlations (see Fig. 13).

In more detail, in the basal interval shallow subtidal dolostones prevail, and are subsequently overlain by a thick terrigenous interval in which coastal sabkha evaporites frequently occur. This basal regressive interval probably corresponds, in the Dordolla and Rio Pontuz sections, to the superposition of the mudflat and sabkha facies associations (FA10 and FA11) over lagoonal and tidal flat carbonates (FA8 and FA9). Moreover, the upper part of the succession in the Dolomites is characterized by the prevalence of intertidal/subtidal dolostones, and transition to the overlying Dolomia Principale peritidal cycles occurs by gradual decrease of siliciclastic interbeds, strictly recalling the successions in Eastern Carnia and western Julian Alps (Braga et al., 1971; Carulli et al., 1987, 1998; Zanferrari et al., 2013).

The depositional model outlined in this study completes, in a basinward direction, the depositional system described in the Dolomites by Breda \& Preto (2011). Carbonate-siliciclastic cycles related to fluctuations from a coastal mudflat to a shallow lagoon environment occur at the base of sections in the Dolomites, Val Dogna and eastern Carnia. Most carbonate successions occur to the north; therefore, it is probable that a margin platform system occurred few kilometres northward close to the Insubric Line (Gianolla et al., 2010).

In the External Dinarides region, Carnian bauxites are overlain by Tuvalian carbonate-siliciclastic successions grading upward to carbonate peritidal facies of the Main Dolomite (Celarc, 2008; Dozet \& Buser, 2009). However, more 
detailed studies are needed to identify transgressive-regressive cycles that may allow extraregional correlations.

\section{Comparison with other high-relief carbonate platforms of the Palaeozoic and Mesozoic}

The outer platform to slope facies associations outline a microbial-dominated carbonate factory (M-factory, sensu Schlager, 2003) and, despite an obvious difference of scale, show patterns that are partly comparable with high-relief, Anisian build-ups of the Dolomites (for example, the Cernera and Latemar platforms; Gaetani et al., 1981; Harris, 1993; Brack et al., 2007; Marangon et al., 2011). In the Latemar platform, the outer platform and shelf break are made of microbial boundstones with calcareous sponges, Tubiphytes and early marine cements, plus patches of bioclastic grainstones. Upper slope facies are also microbial boundstones, characterized by abundant syndepositional cements and Tubiphytes. The lower slope is dominated by detrital grainstone, rudstone and breccia with clasts derived from the marginal and slope boundstone. Because the M-factory was relatively independent from limiting factors such as light (Kenter et al., 2005), it was productive also below the photic zone, down to a depth of $250 \mathrm{~m}$. This is similar to what occurred in the marginal system of the Dolomia Principale carbonate platform, from the platform edge to the upper slope. The capability to produce carbonate sediment on a wide portion of the platform margin/upper slope allowed the system to produce sediment also during periods when the lagoon was fully exposed and the coastal mudflat reached the shelf crest. This process was observed also for Carboniferous microbial platforms of the Asturias (Spain) and PreCaspian Basin (Kazakhstan), and is called 'slope shedding' (Kenter et al., 2005). Moreover, similarly to the Latemar platform, the Dolomia Principale start-up coincided with regional high subsidence rates (Gianolla et al., 1998), but the platform was able to keep pace with the Tuvalian relative sea-level rise without drowning.

Despite similarities in margin to slope settings, the general architecture of the Dolomia Principale carbonate platform is noticeably different with respect to the Latemar or other Middle Triassic platforms of the Dolomites. Instead, the facies belt organization is more like one of the most studied carbonate platforms of the
Palaeozoic, i.e. the Middle Permian Capitan Reef complex (New Mexico and west Texas, USA). In the Permian example, calcareous encrusters (Tubiphytes, sponges and algae) and early marine cements are the main constituents of the upper slope facies associations, passing inward to bioclastic grainstones (Mazzullo \& Cys, 1977; Babcock \& Yurewicz, 1989; Tinker, 1998). In the outer platform, bedding becomes well-defined and grainstones/packstones (often cross-bedded) predominate over wackestones and algal boundstones. Similar to the Dolomia Principale platform system, fenestral fabrics become common inward and tepee structures with pisolitic internal sediment occur together with skeletal sands, to form a shelf-crest zone with diffused soil crusts (Esteban \& Pray, 1977; Mazzullo \& Birdwell, 1989; Tinker, 1998; and references therein). Grain size and fabrics of pisoids are also comparable to those of the Dolomia Principale shelf crest. This facies belt was subaerially exposed at times, acted as a barrier for the open sea water, and separated bioclastic grainstones of the outer platform from inner platform dolomicrites. These often barren dolostones, related to a shallow hypersaline coastal lagoon (Sarg, 1981), have been found interstratified with algal stromatolites, evaporites and thin layers of sandstones (Nance, 1988), the latter testifying to the occurrence of an alluvial plain dominated by aeolian dunes and ephemeral streams behind the platform system. Apart from the coarser grain size of the siliciclastic component, the overall depositional system of the Permian Capitan Reef is remarkably similar to that of the Tuvalian of the Southern Alps. Siliciclastic sediments also have been interpreted to have bypassed the outer platform at Capitan Reef (Melim \& Scholle, 1995; Saller et al., 2000) and shed into the basin.

The Dolomia Principale carbonate platform can be compared to coeval epicontinental platforms of the Northern Calcareous Alps and Transdanubian Range (Mandl, 2000; Krystyn et al., 2009; Haas et al., 2010a, 2012; Gawlick \& Missoni, 2013). However, the depositional geometries of these systems are poorly preserved with respect to the Dolomia Principale of the Southern Alps, and the facies architecture is difficult to reconstruct. Most of the proposed depositional models are referred to the Early Norian and feature reef-rimmed systems developing from initial open platform configurations (Mandl, 2000; Kenter \& Schlager, 2009; Krystyn 
et al., 2009), with a shallow lagoon behind the margin system, connected inward with restricted environments where dolomitic peritidal cycles formed (Hauptdolomit; in Mandl, 2000; Haas, 2012; Haas et al., 2006, 2015). On the margin to upper slope, sponges and scleractinian corals were the main reef builders, whereas microbialites, Tubiphytes and other encrusters occurred as minor components (Dullo, 1980; Wurm, 1982; Flügel, 2002; Bernecker, 2005; Haas et al., 2010b). Few cases are instead constrained to the Late Tuvalian time (Martindale et al., 2013), showing features partly similar to the Dolomia Principale carbonate platform; thinbedded periplatform basinal limestones are overlain by a prograding platform whose fore reef to reefal facies are characterized by microbialites as primary reef builders. Similar to the upper slope of the Dolomia Principale platform, microbial fabrics and marine cements have been found, encrusting skeletal builders together with hypercalcifying sponges, Tubiphytes and other encrusting microproblematica (Martindale et al., 2013). Unfortunately, there are no data about early-stage inner platform environments and on the possible occurrence of a pisoidal/tepee belt as in the case of the Dolomia Principale platform.

\section{CONCLUSIONS}

The aim of this paper is to better understand the early development of one of the widest epicontinental platforms of the Mesozoic, the Dolomia Principale/Hauptdolomit carbonate platform. The study was carried out by analysing several stratigraphic sections in the northeastern part of the Southern Alps with a multidisciplinary approach. With respect to previous research on the same topic, analysis of sedimentology and spatial relationships between different elements of the carbonate platform has been carried out with more detail and on a larger scale, enabling the complete depiction, for the first time, of the early stage of this depositional system.

The platform started up during the late Tuvalian on a previously flat palaeotopography. In contrast to small and mostly isolated Lower Carnian build-ups, this new carbonate platform extended over hundreds of kilometres on the western Tethys margin. Nucleation of the margin occurred mainly on a WNW-ESE-oriented belt, well-identifiable in the western Julian Alps, but probably extended laterally. The marginal belt was characterized by a high-energy outer platform zone facing a northern basin, and an often emerged belt protecting the inner platform. The platform nucleation point was located a few hundreds of metres south of the first margin to slope outcrop. Behind this marginal barrier, shallow lagoon to tidal flat environments existed, and passed laterally to coastal mudflat and sabkha environments, connected to the south to a semi-arid alluvial plain.

Stratigraphic correlations are established with the Dolomites, more than $100 \mathrm{~km}$ to the west. From this correlation, it can be argued that an outer platform system very similar to that of the western Julian Alps was located a few kilometres north of the northern Dolomites, as partly postulated by Breda \& Preto (2011) and Preto et al. (2015). The early development of the Dolomia Principale platform was in a time of transgression but, despite this, the platform was able to aggrade and prograde, expanding to the north for more than $2 \mathrm{~km}$ before the end of the Tuvalian.

The margin to slope facies associations of the Tuvalian Dolomia Principale are similar to those of Palaeozoic and Triassic microbial platforms, and the platform grew steep slopes and a depositional relief of hundreds of metres on the sea floor (for example, Fig. 5). Microbialites occurred in the skeletal factory of late Julian to early Tuvalian ramps of the Dolomites only as minor components $(<10 \%$; Dal Corso et al., 2015; Gattolin et al., 2015) and were unable to build up significant relief. The Late Carnian emplacement of the Dolomia Principale carbonate platform thus represents the return, in the western Tethys, to high-relief build-ups after a late Julian demise (Schlager \& Schollnberger, 1974; Flügel, 2002; Gianolla et al., 2003; Keim et al., 2006; Stefani et al., 2010; Lukeneder et al., 2012; Gattolin et al., 2015) and may be viewed, in terms of shallow-water carbonate systems, as marking the end of the prolonged environmental perturbation known as the Carnian Pluvial Event. The margin to slope microbial-dominated carbonate factory of the earlystage Dolomia Principale carbonate platform fits well with other coeval reef communities of Western Tethys (Bernecker, 2005; Martindale et al., 2015) and slightly precedes the Late Carnian-Early Norian biological turnover (Flügel, 2002; Kiessling, 2009) that caused the microbialites to occur only as accessories in coralsponge-dominated reefs. 


\section{ACKNOWLEDGEMENTS}

PhDs Luka Gale (University of Ljubljana) and Giovanni Gattolin (ENI) are thanked for assistance in the field campaign and data support. Mr Renzo Tamoni (University of Ferrara) is acknowledged for thin and polished section preparation, the U.T.I. Canal del Ferro-Val Canale for special permits. We would also kindly thank the anonymous referees for their careful reviews and suggestions that improved the manuscript, as well as Associate Editor Eberli. The research was supported by PRIN 2010-2011 funds (Pr. No. 20107ESMX9_004), financed by the Italian Government, and by Program number P1-0011, financed by the Slovenian Research Agency.

\section{REFERENCES}

Assereto, R., Desio, A., Di Colbertaldo, D. and Passeri, L.D. (1968) Note illustrative della Carta Geologica d'Italia alla scala 1:100.000. Foglio 14, Tarvisio, Servizio Geologico d'Italia, 1-70.

Avanzini, M., Dalla Vecchia, F.M., Mietto, P., Piubelli, D., Preto, N., Rigo, M. and Roghi, G. (2007) A vertebrate nesting site in Northeastern Italy reveals unexpectedly complex behavior of late Carnian reptiles. Palaios, 22, $465-475$.

Babcock, J.A. and Yurewicz, D.A. (1989) The massive facies of the Capitan Limestone, Guadalupe Mountains, Texas and New Mexico. In: Subsurface and Outcrop Examination of the Capitan Shelf Margin, Northern Delaware Basin (Eds P.M. Harris and G.A. Grover), SEPM Core Workshop No. 13, 365-371.

Balini, M., Lucas, S. G., Jenks, J. F. and Spielmann, J. A. (2010) Triassic ammonoid biostratigraphy: an overview. Geol. Soc. Spec. Pub., 334, 221-262.

Bernecker, M. (2005) Late Triassic reefs from the Northwest and South Tethys: distribution, setting, and biotic composition. Facies, 51, 442-453.

Berra, F., Jadoul, F. and Anelli, A. (2010) Environmental control on the end of the Dolomia Principale/ Hauptdolomit depositional system in the central Alps: coupling sea-level and climate changes. Palaeogeogr. Palaeoclimatol. Palaeoecol., 290, 138-150.

Bianchin, G., Carulli, G.B. and Frizzo, P. (1980) Carta geologica della zona tra il T. Chiarzo' e il F. Fella (Alpi Carniche). Giorn. Geol., 49, 1-32.

Blendinger, W. (1994) The carbonate factory of Middle Triassic buildups in the Dolomites, Italy - a quantitative analysis. Sedimentology, 41, 1147-1159.

Bosellini, A. (1967) La tematica deposizionale della Dolomia Principale (Dolomiti e Prealpi Venete). Boll. Soc. Geol. It., 86, 133-169.

Bosellini, A. (1984) Progradation geometries of carbonate platforms: examples from the Triassic of the Dolomites, northern Italy. Sedimentology, 31, 1-24.

Bosellini, A. and Hardie, L.A. (1985) Facies e cicli della Dolomia principale delle Prealpi venete. Mem. Soc. Geol. It., 30, 245-266.
Brack, P., Rieber, H., Mundil, R., Blendinger, W. and Maurer, F. (2007) Geometry and chronology of growth and drowning of Middle Triassic carbonate platforms (Cernera and Bivera/Clapsavon) in the Southern Alps (northern Italy). Swiss J. Geosci., 100, 327-348.

Braga, G., Carloni, G.V., Colantoni, P., Corsi, M., Cremonini, G., Frascari, F., Locatelli, D., Monesi, A., Pisa, G., Sassi, F.P., Selli, R., Vai, G.B. and Zirpoli, G. (1971) Fogli 4c-13 Monte Cavallino- Ampezzo. Carta Geologica d'Italia alla scala 1:100000, Servizio Geologico d'Italia, 1-109.

Breda, A. and Preto, N. (2011) Anatomy of an Upper Triassic continental to marginal-marine system: the mixed siliciclastic-carbonate Travenanzes Formation (Dolomites, Northern Italy). Sedimentology, 58, 1613-1647.

Breda, A., Preto, N., Roghi, G., Furin, S., Meneguolo, R., Ragazzi, E., Fedele, P. and Gianolla, P. (2009) The Carnian Pluvial Event in the Tofane area (Cortina d'Ampezzo, Dolomites, Italy). Geo. Alp, 6, 80-115.

Brusca, C., Gaetani, M., Jadoul, F. and Viel, G. (1981) Paleogeografia Ladino- Carnica e metallogenesi nel Sudalpino. Mem. Soc. Geol. It., 22, 65-82.

Carulli, G.B., Frizzo, P., Longo Salvador, G., Semenza, E., Bianchin, G., Mantovani, F. and Mezzacasa, G. (1987) La geologia della zona tra il T. Chiarzò e il F. Fella (Alpi Carniche). Giorn. Geol., 49, 1-32.

Carulli, G.B., Fantoni, R., Masetti, D., Ponton, M., Trincianti, E., Trombetta, G.L. and Venturini, S. (1998) Analisi di facies e proposta di revisione stratigrafica del Triassico Superiore del Sudalpino orientale. Atti Tic. Sc. Terra, 7, 159-183.

Carulli, G.B., Cozzi, A., Longo Salvador, G., Pernarcic, E., Podda, F. and Ponton, A. (2000) Geologia delle Prealpi Carniche. Udine.

Castellarin, A., Nicolich, R., Fantoni, R., Cantelli, L., Sella, M. and Selli, L. (2006) Structure of the lithosphere beneath the Eastern Alps (southern sector of the TRANSALP transect). Tectonophysics, 414, 259-282.

Cati, A., Sartorio, D. and Venturini, S. (1987) Carbonate platforms in the subsurface of the Northern Adriatic Area. Mem. Soc. Geol. It., 40, 295-308.

Catuneanu, O., Galloway, W.E., Kendall, C.G.S., Miall, A.D., Posamentier, H.W., Strasser, A. and Tucker, M.E. (2011) Sequence stratigraphy: methodology and nomenclature. Newsl. Stratigr., 44, 173-245.

Celarc, B. (2008) Carnian bauxite horizon on the Kopitov grič near Borovnica (Slovenia) - is there a "forgotten« stratigraphic gap in its footwall? Geologija, 51, 147-152.

Celarc, B. and Kolar-Jurkovšek, T. (2008) The CarnianNorian basin- platform system of the Martuljek Mountain Group (Julian Alps, Slovenia): progradation of the Dachstein carbonate platform. Geol. Carpath., 59, 211-224.

Cozzi, A. and Hardie, L.A. (2003) Third-order depositional sequences controlled by synsedimentary extensional tectonics: evidence from Upper Triassic carbonates of the Carnian Prealps (NE Italy). Terra Nova, 15, 40-45.

Dal Corso, J., Gianolla, P., Newton, R.J., Franceschi, M., Roghi, G., Caggiati, M., Raucsik, B., Budai, T., Haas, J. and Preto, N. (2015) Carbon isotope records reveal synchronicity between carbon cycle perturbation and the "Carnian Pluvial Event" in the Tethys realm (Late Triassic). Global Planet. Change, 127, 79-90.

De Marco, S., Fantoni, R., Ponton, M. and Scotti, P. (2000) Cave del Predil: la successione di Raibl. In: $80^{\circ}$ Riunone Estiva Della Società Geologica Italiana (Ed. G.B. Carulli), pp. 102-115. Trieste, 6-8 settembre’ 2000. Guida alle escursioni. 
De Zanche, V., Gianolla, P., Mietto, P., Sorpaes, C. and Vail, P.R. (1993) Triassic sequence stratigraphy in the Dolomites (Italy). Mem. Sci. Geol., 45, 1-23.

De Zanche, V., Gianolla, P. and Roghi, G. (2000) Carnian stratigraphy in the Raibl/Cave del Predil area (Julian Alps, Italy). Eclogae Geol. Helv., 93, 331-347.

Dozet, S. and Buser, S. (2009) Triassic. In: The Geology of Slovenia (Eds M. Pleničar, B. Ogorelec and M. Novak), Geološki Zavod Slovenije, 161-214.

Dullo, W.-C. (1980) Paläontologie, Fazies und Geochemie der Dachstein-Kalke (Ober-Trias) im südwestlichen Gesäuse, Steiermark, Österreich. Facies, 2, 55-121.

Esteban, M. and Pray, L.C. (1977) Origin of the pisolite facies of the shelf crest. In: Upper Guadalupian Facies, Permian Reef Complex, Guadalupe Mountains, New Mexico and West Texas (1977 Field Conference Guidebook) (Eds M.E. Hileman and S.J. Mazzullo), SEPM, 77-16, 479-486.

Flügel, E. (2002) Triassic reef patterns. In: Phanerozoic Reef Patterns (Eds W. Kiessling, E. Flügel and J. Golonka), SEPM Spec. Publ., 72, 391-463.

Fruth, I. and Scherreiks, R. (1984) Hauptdolomitsedimentary and paleogeographic models (Norian, Northern Calcareous Alps). Geol. Rundsch., 73, 305-319.

Gaetani, M., Fois, E., Jadoul, F. and Nicora, A. (1981) Nature and evolution of Middle Triassic carbonate buildups in the Dolomites (Italy). Mar. Geol., 44, 2557.

Gale, L., Celarc, B., Caggiati, M., Kolar-Jurkovšek, T., Jurkovšek, B. and Gianolla, P. (2015) Development and palaeogeographic meaning of the Late Triassic basinal succession of the Tamar Valley, northern Julian Alps, Slovenia. Geol. Carpath., 66, 269-283.

Gattolin, G., Preto, N., Breda, A., Franceschi, M., Isotton, M. and Gianolla, P. (2015) Sequence stratigraphy after the demise of a high-relief carbonate platform (Carnian of the Dolomites): sea-level and climate disentangled. Palaeogeogr. Palaeoclimatol. Palaeoecol., 423, 1-17.

Gawlick, H.-J. and Missoni, S. (2013) Field Trip B2: Triassic to Early Cretaceous geodynamic history of the central Northern Calcareous Alps (Northwestern Tethyan realm). Berichte Geol. B.-A., 99, 216-270.

Ghosh, P., Sarkar, S. and Maulik, P. (2006) Sedimentology of a muddy alluvial deposit: Triassic Denwa Formation, India. Sed. Geol., 191, 3-36.

Gianolla, P., De Zanche, V. and Mietto, P. (1998) Triassic sequence stratigraphy in the Southern Alps (Northern Italy): definition of sequences and basin evolution. In: Mesozoic-Cenozoic Sequence Stratigraphy of European Basins (Eds P.C. de Gracianscky, J. Hardenbol, T. Jacquin, P.R. Vail and D. Ulmer-Scholle), SEPM Spec. Publ., 60, 723-751.

Gianolla, P., De Zanche, V. and Roghi, G. (2003) An Upper Tuvalian (Triassic) platform-basin system in the Julian Alps: the start-up of the Dolomia Principale (Southern Alps, Italy). Facies, 49, 135-150.

Gianolla, P., Mietto, P., Rigo, M., Roghi, G. and De Zanche, V. (2010) Carnian-Norian paleogeography in the eastern Southern Alps. Albertiana, 39, 67-68.

Guembel, C.W. (1857) Untersuchungen in den bayerischen Alpen zwischen Isar und Salzach. Jahrb. K.K Geol. Reich., 7, 146-151.

Haas, J. (2012) Geology of Hungary. Regional Geology Reviews. Springer, Berlin, Heidelberg, 244 p.
Haas, J., Lobitzer, H. and Monostori, M. (2006) Characteristics of the Lofer cyclicity in the type locality of the Dachstein Limestone (Dachstein Plateau, Austria). Facies, 53, 113-126.

Haas, J., Götz, A.E. and Pálfy, J. (2010a) Late Triassic to Early Jurassic palaeogeography and eustatic history in the NW Tethyan realm: new insights from sedimentary and organic facies of the Csővár Basin (Hungary). Palaeogeogr. Palaeoclimatol. Palaeoecol., 291, 456-468.

Haas, J., Piros, O., Budai, T., Görög, A., Mandl, G.W. and Lobitzer, H. (2010b) Transition between the massive reefbackreef and cyclic lagoon facies of the Dachstein Limestone in the southern part of the Dachstein Plateau, Northern Calcareous Alps, Upper Austria and Styria. Abh. Geol. B.-A., 65, 35-56.

Haas, J., Budai, T. and Raucsik, B. (2012) Climatic controls on sedimentary environments in the Triassic of the Transdanubian Range (Western Hungary). Palaeogeogr. Palaeoclimatol. Palaeoecol., 353-355, 31-44.

Haas, J., Lukoczki, G., Budai, T. and Demény, A. (2015) Genesis of Upper Triassic peritidal dolomites in the Transdanubian Range, Hungary. Facies, 61, 1-28.

Harris, M.T. (1993) Reef fabrics, biotic crusts and syndepositional cements of the Latemar reef margin (Middle Triassic), northern Italy. Sedimentology, 40, 383401.

Iannace, A. and Zamparelli, V. (2002) Upper Triassic platform margin biofacies and the paleogeography of Southern Apennines. Palaeogeogr. Palaeoclimatol. Palaeoecol., 179, 1-18.

Jadoul, F. and Nicora, A. (1979) L'assetto stratigraficopaleogeografico del Trias Medio-Superiore della Val d'Aupa (Carnia orientale). Riv. Ital. Paleontol. Stratigr., 85, $1-30$.

Jadoul, F., Galli, M.T., Berra, F., Cirilli, S., Ronchi, P. and Paganoni, A. (2004) The Late Triassic-Early Jurassic of the Lombardy Basin: Stratigraphy, Palaeogeography and Palaeontology. 32nd IGC Florence August 20-28 2004, Excursion Guide book, 68, $36 \mathrm{pp}$.

Keim, L., Spotl, C. and Brandner, R. (2006) The aftermath of the Carnian carbonate platform demise: a basinal perspective (Dolomites, Southern Alps). Sedimentology, 53, 361-386.

Kenter, J.A.M. and Schlager, W. (2009) Slope angle and basin depth of the Triassic platform basin transition at the Gosaukamm, Austria. Aust. J. Earth Sci., 102, 15-22.

Kenter, J.A.M., Harris, P.M. and Della Porta, G. (2005) Steep microbial boundstone-dominated platform marginsexamples and implications. Sed. Geol., 178, 5-30.

Kiessling, W. (2009) Geologic and biologic controls on the evolution of reefs. Annu. Rev. Ecol. Evol. Syst., 40, 173192.

Kovács, S., Sudar, M., Grădinaru, E., Gawlick, H.-J., Karamata, S., Haas, J., Péró, C., Gaetani, M., Mello, J., Polák, M., Aljinović, D., Ogorelec, B., Kolar-Jurkovšek, T., Jurkovšek, B. and Buser, S. (2011) Triassic evolution of the tectonostratigraphic units of the Circum-Pannonian Region. Jahrb. Geol. Bund., 151, 199-280.

Krystyn, L., Mandl, G.W. and Schauer, M. (2009) Growth and termination of the Upper Triassic platform margin of the Dachstein area (Northern Calcareous Alps, Austria). Aust. J. Earth Sci., 102, 22-33.

Lehrmann, D.J., Jiayong, W.E.I. and Enos, P. (1998) Controls on facies architecture of a large Triassic carbonate 
platform: the great bank of Guizhou, Nanpanjiang basin, South China. J. Sediment. Res., 68, 311-326.

Lehrmann, D.J., Enos, P., Payne, J.L., Montgomery, P., Wei, J., Yu, Y., Xiao, J. and Orchard, M.J. (2005) Permian and Triassic depositional history of the Yangtze platform and Great Bank of Guizhou in the Nanpanjiang basin of Guizhou and Guangxi, south China. Albertiana, 33, 147166.

Lepsius, R. (1876) Einteilung der alpinen Trias und ihr Verhaltnis zur Ausseralpinen. N. Jb. Min. Geol. Paläont., 742-744.

Lieberman, H.M. (1978) Carnitza formation. Mitt. Ges. Geol. Bergbaustud. Österr., 25, 35-60.

Lukeneder, S., Lukeneder, A., Harzhauser, M., İslamoğlu, Y., Krystyn, L. and Lein, R. (2012) A delayed carbonate factory breakdown during the Tethyan-wide Carnian Pluvial Episode along the Cimmerian terranes (Taurus, Turkey). Facies, 58, 279-296.

Mandl, G.W. (2000) The Alpine sector of the Tethyan shelf examples of Triassic to Jurassic sedimentation and deformation from the Northern Calcareous Alps. Mitt. Osterr. Geol. Ges., 92, 61-77.

Marangon, A., Gattolin, G., Della Porta, G. and Preto, N. (2011) The Latemar: a flat-topped, steep fronted platform dominated by microbialites and synsedimentary cements. Sed. Geol., 240, 97-114.

Martindale, R.C., Krystyn, L., Corsetti, F.A. and Bottjer, D.J. (2013) From fore reef to lagoon: evolution of the upper Triassic Dachstein carbonate platform on the Tennengebirge (Salzburg, Austria). Palaios, 28, 755-770.

Martindale, R.C., Corsetti, F.A., James, N.P. and Bottjer, D.J. (2015) Paleogeographic trends in Late Triassic reef ecology from northeastern Panthalassa. Earth Sci. Rev., 142, 1837.

Mazzullo, S.J. and Birdwell, B.A. (1989) Syngenetic formation of grainstones and pisolites from fenestral carbonates in peritidal settings. J. Sed. Res., 59, 605-611.

Mazzullo, S.J. and Cys, J.M. (1977) Submarine cements in Permian boundstones and reef-associated rocks, Guadalupe Mountains, west Texas and southeastern New Mexico. In: Upper Guadalupian Facies, Permian Reef Complex, Guadalupe Mountains, New Mexico and West Texas (1977 Field Conference Guidebook) (Eds M.E. Hileman and S.J. Mazzullo), SEPM Publication 77-16, 151-200.

Melim, L.A. and Scholle, P.A. (1995) The forereef facies of the Permian Capitan Formation; the role of sediment supply versus sea-level changes. J. Sed. Res., 65, 107-118.

Nance, H.S. (1988) Interfingering of evaporites and red beds: an example from the Queen/Grayburg formation, Texas. Sed. Geol., 56, 357-381.

Ponton, M. (2010) Architettura delle Alpi Friulane. Museo Friulano St. Nat., Udine, 80 p.

Preto, N., Roghi, G. and Gianolla, P. (2005) Carnian stratigraphy of the Dogna area (Julian Alps, northern Italy): tessera of a complex palaeogeography. Boll. Soc. Geol. It., 124, 269-279.

Preto, N., Willems, H., Guaiumi, C. and Westphal, H. (2012) Onset of significant pelagic carbonate accumulation after the Carnian Pluvial Event (CPE) in the western Tethys. Facies, 59, 891-914.

Preto, N., Breda, A., Dal Corso, J., Spötl, C., Zorzi, F. and Frisia, S. (2015) Primary dolomite in the Late Triassic Travenanzes Formation, Dolomites, Northern Italy: facies control and possible bacterial influence. Sedimentology, 62, 697-716.
Roghi, G. (2004) Palynological investigations in the Carnian of the Cave del Predil area (Julian Alps, NE Italy). Rev. Palaeobot. Palynol., 132, 1-35.

Roghi, G. and Dalla Vecchia, F.M. (1997) The palynology and palaeoenviroment of the Upper Triassic dolomiticmarly sequence of Dogna valley (Udine, Friuli-Venezia Giulia, NE Italy) with reptile trackways. Riv. Ital. Paleontol. Stratigr., 103, 183-192.

Russo, F., Neri, C., Mastandrea, A. and Baracca, A. (1997) The mud mound nature of the Cassian platform margins of the Dolomites. A case history: the Cipit boulders from Punta Grohmann (Sasso Piatto Massif, morthern Italy). Facies, 36, 25-36.

Ruvinetti, R. (2004) Molluschi bentonici e brachiopodi nell'evoluzione paleoambientale e paleoclimatica del Carnico medio del Sudalpino orientale. Unpublished PhD thesis, University of Ferrara, $190 \mathrm{pp}$.

Saller, A.H., Harris, P.M., Kirkland, B. and Mazzullo, S.J. (2000) Geologic Framework of the Capitan Reef. SEPM Spec. Publ., 65, 224 pp.

Sarg, J.F. (1981) Petrology of the carbonate-evaporite facies transition of the Seven Rivers Formation (Guadalupian, Permian), Southeast New Mexico. J. Sed. Res., 51, 73-96.

Schlager, W. (2003) Benthic carbonate factories of the Phanerozoic. Int. J. Earth Sci., 92, 445-464.

Schlager, W. and Schollnberger, W. (1974) Das Prinzip stratigraphischer Wenden in der Schichtfolge der Nördlichen Kalkalpen. Mitt. Österr. Geol. Ges., 66-67, 165-193.

Simms, M.J. and Ruffell, A.H. (1989) Synchroneity of climatic change and extinctions in the Late Triassic. Geology, 17, 265-268.

Stefani, M., Furin, S. and Gianolla, P. (2010) The changing climate framework and depositional dynamics of Triassic carbonate platforms from the Dolomites. Palaeogeogr. Palaeoclimatol. Palaeoecol., 290, 43-57.

Tinker, S.W. (1998) Shelf-to-basin facies distributions and sequence stratigraphy of a steep-rimmed carbonate margin; Capitan depositional system, McKittrick Canyon, New Mexico and Texas. J. Sed. Res., 68, 1146-1174.

Tollmann, A. (1977) Geologie von Osterreich. Deuticke, Wien, $766 \mathrm{p}$.

Tollmann, A. (1980) Geology and tectonics of the Eastern Alps (middle sector). Abh. Geol. B.-A., 34, 197-255.

Venturini, C. (2002) Carta geologica delle Alpi Carniche. Udine, Museo Friul. di Storia Nat.

Vlahović, I., Tišljar, J., Velić, I. and Matičec, D. (2005) Evolution of the Adriatic Carbonate Platform: palaeogeography, main events and depositional dynamics. Palaeogeogr. Palaeoclimatol. Palaeoecol., 220, 333-360.

Wright, V.P. and Sandler, A. (1994) A hydrogeological model for the early diagenesis of Late Triassic alluvial sediments. Q. J. Geol. Soc. London, 151, 897-900.

Wurm, D. (1982) Microfacies, paleontology and palecology of the Dachstein Reef Limestones (Norian) of the Gosaukamm Range, Austria. Facies, 6, 203-296.

Zanferrari, A., Masetti, D., Monegato, G. and Poli, M.E. (2013) Note Illustrative - Foglio 049 Gemona del Friuli, Carta Geologica d'Italia alla Scala 1:50000. Udine, ISPRA, $262 \mathrm{p}$.

Manuscript received 10 October 2016; revision accepted 21 September 2017 
The start-up of the D.P. carbonate platform 1131

\section{Supporting Information}

Additional Supporting Information may be found in the online version of this article:
Table S1. Geographic coordinates of investigated sections with a list of the relative most important published works. 